\title{
SOME CONTROVERSIAL ASPECTS OF THE SEISMIC DESIGN OF REINFORCED CONCRETE BUILDING STRUCTURES
}

\author{
Bob Park ${ }^{1}$ \\ Invited Keynote Address at the fib (International Federation of Structural Concrete) International Symposium on Concrete \\ Structures in Seismic Regions, Athens, 6-9 May 2003.
}

\begin{abstract}
Significant differences exist between the recommendations for seismic design of the codes and guidelines for reinforced concrete of different countries. Performance criteria for building structure to avoid unacceptable damage during various levels of earthquake hazard need to be refined. More accurate recommendation for the effective flexural rigidity of reinforced concrete members are required for linear elastic structural analysis to enable better estimates of the periods of vibration and the lateral deflections of statically indeterminate structures including the effects of cracking of concrete. Current code recommended values for flexural rigidity will generally lead to estimates of the periods of vibration and lateral deflections, which are on the low side. The capacity design approach to ensure the most appropriate mechanism of yielding will occur in the event of a severe earthquake is generally recognized by codes but to varying degrees of clarity, and the degrees to which capacity design is incorporated in each code varies significantly. High strength concrete and high strength non-prestressed steel reinforcement can be used in the design of buildings but the brittle behaviour of high strength concrete and the unusable yield strength of high strength steel reinforcement need to be considered. Important differences between codes exist in the rules for the quantity of confining reinforcement placed in reinforced concrete columns to ensure ductile behaviour. Significant differences also exist between the quantities of shear and confining reinforcement required in beam-column joints and in the anchorage of length of longitudinal reinforcement passing through beam-column joints. Precast concrete structures can be designed successfully for earthquake resistance but design codes in seismic regions contain provisions for precast concrete to varying degrees.
\end{abstract}

Keywords: beam-column joints, capacity design, columns, confining reinforcement, controversial aspects of design, earthquake resistance, high strength materials, moment resisting frames, performance criteria, precast concrete, seismic design

\section{INTRODUCTION}

During the last fifty or so years a great deal of research and development has been conducted into aspects of the design of reinforced concrete building structures subjected to seismic actions. Based on the results of laboratory tests involving simulated seismic forces and the observed behaviour of structures during actual earthquakes, design recommendations have been developed and incorporated in the seismic design codes of the various countries. It is of concern that some of the recommended approaches for the design of reinforced concrete structures in Europe [1], Japan [2], the USA [3] and New Zealand [4] very significantly mainly due to different interpretations of test data, different models of behavior and different performance criteria.

This paper discusses some of the controversial aspects of these differences. The paper includes coverage of items such as performance criteria, flexural rigidity of members, capacity design, the use of high strength materials, the design of confining reinforcement in columns, the design of beamcolumn joints and the design of precast concrete buildings.

Emeritus Professor of Civil Engineering, University of Canterbury, Private Bag 4800, Christchurch (Life Member \& Ex-President)

\section{PERFORMANCE CRITERIA FOR REINFORCED CONCRETE BUILDINGS}

For many years building codes have recommended design seismic actions for building structures which are generally much less than the inertia forces induced if structures responded in the elastic range to severe earthquakes. In such cases codes have relied on the dissipation of seismic energy by ductile post-elastic deformations of the structure in order to survive a severe earthquake. The occurrence of post-elastic strains in a reinforced concrete structure during an earthquake implies a degree of damage at the yielding regions.

The criteria for the levels of seismic force set by the codes of many countries has been: buildings should be able to resist moderate earthquakes with moderate damage and to resist severe earthquakes without collapse. The main emphasis has been on life safety. More refined criteria have been introduced into some codes.

For example the performance criteria specified in the New Zealand code for general structural design [5] for seismic design are:

(a) Serviceability limit state: the structure should have sufficient stiffness and strength to resist moderate 
earthquakes (with a return period of about 10 years) without damage. That is during moderate earthquakes the structure should remain essentially in the elastic range with limited interstorey lateral deflections.

(b) Ultimate limit state: the structure should have sufficient stiffness, strength and ductility to resist severe earthquakes (with a return period of about 450 years) without endangering life, or for important buildings causing loss of function, or causing damage to high value contents, or causing inappropriate damage to non-structural elements, or exceeding building separations, or causing loss of structural integrity. At the ultimate limit state the maximum interstorey drift (defined as the interstorey horizontal deflection divided by the storey height) should not exceed $1.5 \%$ to $2.0 \%$ depending on the height of the building.

More refinement of performance criteria is required in codes to avoid unacceptable economic loss after an earthquake for various levels of seismic hazard. For example, under current criteria a structure may be left standing after an earthquake but may be a total economic loss, a point that most building owners may are not be aware of.

Performance-based engineering has been discussed in several publications. For example, by the Structural Engineers Association of California, USA [6], by Okada, et al of Japan [7] and by Priestley of USA/New Zealand [8]. Agreement has yet to be reached on many aspects of performance-based design. Nevertheless the implication is that designers should be able to design a structure to perform at a specified performance level in response to an earthquake of a specified earthquake hazard level. A specified performance level is a required degree of functionality after it experiences an earthquake. An earthquake hazard level is a measure of the severity of earthquake effects at a given site.

As an example of the application of performance-based seismic design it is contended by Priestley [8] that two performance limit states should be considered in seismic design, namely: Fully Operational and Damage Control.

The aim of the fully operational limit state is for the facility to continue in operation with negligible damage. This limit state can be defined by crushing of concrete and unacceptably large residual crack widths. A concrete compression strain of 0.004 is a reasonable bound for this limit state. Maximum reinforcement tensile strains of 0.01 for beams an 0.015 for columns and walls seem appropriate, since analysis of test data indicates that residual crack widths of reinforced concrete members subjected to peak strains of this level will be in the range of $0.5-1.0 \mathrm{~mm}$ [8]. The definition of a fully operational interstorey drift limit is less obvious since the onset of non-structural damage is very dependent on the design details provided to separate nonstructural elements from structural elements. However, with good detailing non-structural damage should not be evident at interstorey drifts of less than $1 \%$.

The aim of the damage control limit state is for the facility to continue in operation with insignificant and repairable damage. This limit state can also be controlled by material strain limits and by design interstorey drift limits intended to restrict non-structural damage. For example, a limit compression strain for confined concrete could be taken as greater than 0.004 , depending on the amount of confinement by transverse reinforcement. The maximum longitudinal reinforcement tensile strain must be limited to a lesser value than the strain $\varepsilon_{\mathrm{su}}$ at maximum stress to avoid buckling and low cycle fatigue.

In summary, based on performance objectives for a given earthquake hazard level the structure ductility factor or force reduction factor used in design should be the minimum of that associated with the structural damage permitted at the specified performance level and with the interstorey drift associated with limiting the non-structural damage at the specified performance level.

It is evident that the next generation of seismic design codes should pay more attention to performance limit states.

\section{FLEXURAL RIGIDITY OF MEMBERS}

Elastic theory analysis for the determination of internal actions in statically indeterminate structures and for the estimation of the periods of vibration and lateral deflections of structures at the limit states need to include the effects of cracking of concrete on the flexural rigidity of members. This is normally achieved by expressing the effective moment of inertia of the cracked cross section about the centroidal axis, $I_{e}$, as a proportion of the moment of inertia of the gross (uncracked) cross section about the centroidal axis neglecting the reinforcement, $I_{g}$. Although the effects on the flexural rigidity will vary along a member, according to the bending moment pattern, average values for $I_{e}$ applicable to the full length of prismatic members are normally assumed.

The commentary for the New Zealand standard for the design of concrete structures [4] recommends the following $I_{e}$ values for beams, columns and walls at the ultimate limit state:

1. Beams

$\mathrm{I}_{\mathrm{e}}=0.4 \mathrm{I}_{\mathrm{g}}$ for rectangular sections

$\mathrm{I}_{\mathrm{e}}=0.35 \mathrm{I}_{\mathrm{g}}$ for $\mathrm{T}$ or $\mathrm{L}$ sections

2. Columns

$$
\begin{array}{ll}
I_{e}=0.80 I_{g} & \text { for } N^{*} / f_{c}^{\prime} A_{g}>0.5 \\
I_{e}=0.60 I_{g} & \text { for } N^{*} / f_{c}^{\prime} A_{g}=0.2 \\
I_{e}=0.40 I_{g} & \text { for } N^{*} / f_{c}^{\prime} A_{g}=-0.05
\end{array}
$$

3. Structural walls

$$
\begin{array}{ll}
I_{e}=0.45 I_{g} & \text { for } N^{*} / f_{c}^{\prime} A_{g}=0.2 \\
I_{e}=0.25 I_{g} & \text { for } N^{*} / f_{c}^{\prime} A_{g}=0 \\
I_{e}=0.5 I_{g} & \text { for } N^{*} / f_{c}^{\prime} A_{g}=-0.1
\end{array}
$$

where $\mathrm{N}^{*}=$ design axial load on the section, (positive if compression) $f_{c}^{\prime}=$ compressive cylinder strength of concrete and $A_{g}=$ gross area of the section.

Eurocode 8 [1] recommends that unless a more accurate analysis of the cracked elements is performed the flexural rigidity of reinforced concrete elements may be taken as 0.5 $I_{g}$. 
The ACI building code [3] recommends that either $I_{g}$ be used for all members or $0.5 \mathrm{I}_{\mathrm{g}}$ be used for beam stems and $\mathrm{I}_{\mathrm{g}}$ for the columns.

However, Priestley [9] has reported that recent extensive parameter studies of the moment curvature response of columns and structural walls have shown that it is inappropriate to assume that $I_{e}$ is a constant proportion of $I_{g}$ regardless of the reinforcement content and yield strength.

In these studies [9] $\mathrm{I}_{\mathrm{e}}$ was determined from the equation [10]

$$
E_{c} l_{e}=\frac{M_{n}}{\phi_{y}}
$$

where $E_{c}=$ modulus of elasticity of concrete, $M_{n}=$ nominal flexural strength of the section and $\phi_{y}=$ curvature at first yield.

Since $\phi_{y}$ is essentially constant for a given $f_{y}$ [9] this equation implies that the flexural rigidity is proportional to the flexural strength of the member.

T-beams with a range of reinforcement percentages top and bottom and with steel yield strengths of 300 and $400 \mathrm{MPa}$ were investigated by Priestley [9] and it was observed that on average $I_{e}$ varied between 0.16 and 0.44 of $I_{g}$. The values for $I_{e}$ were generally lower than assumed by codes and the range indicates that significant errors in the calculation of the period of vibration and the deflections (generally on the low side) can be expected if $I_{e}$ is assumed to be the code recommended constant fraction of $I_{g}$.

It is evident that codes should recommend better estimates for the flexural rigidity to be used to calculate periods of vibration and lateral deflections of structures.

\section{THE CAPACITY DESIGN APPROACH}

\subsection{Introduction}

Before about the mid 1970s it was customary in the seismic design of structures to use linear elastic structural analysis to determine the bending moments, axial forces and shear forces due to the design gravity loading and seismic forces and to design the members to be at least strong enough to resist those actions.

As a result, when the structure as designed and constructed was subjected to a severe earthquake, the manner of postelastic behaviour was a matter of chance. Flexural yielding of structural members could occur at any of the regions of maximum bending moment, and shear failures could also occur, depending on where the flexural and shear strengths of members were first reached. Hence the behaviour of such structures in the post-elastic range was somewhat unpredictable.

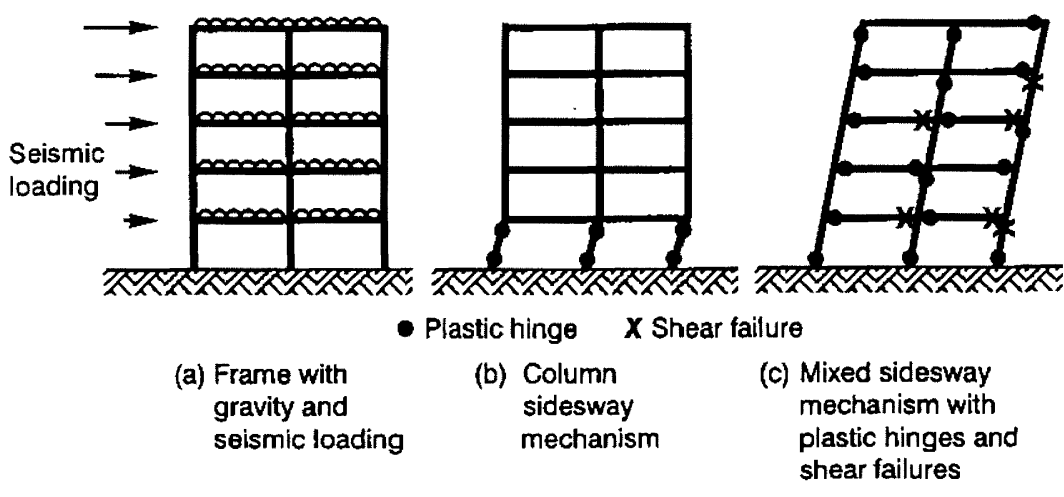

Figure 1. Undesirable modes of behaviour for tall seismically loaded monolithic moment resisting frames in the post-elastic range $[10,11]$.

For example, for monolithic moment resisting frames, overstrength of the beams in flexure or understrength of the columns in flexure could result in column sidesway mechanisms, in the bottom or upper storeys (see Fig. 1b).
Also, flexural overstrength of members leads to increased shear forces when plastic hinges form, which could result in shear failures (see Fig. 1c). These undesirable failure modes could cause catastrophic collapse of the frame.

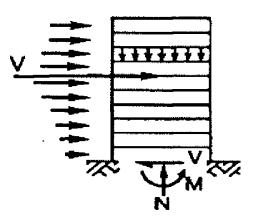

(a) Wall actions

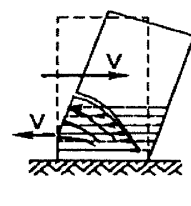

(b) Diagona tension

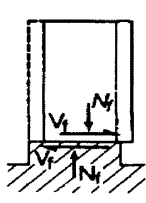

(c) Sliding shear

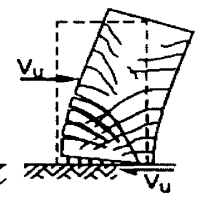

(d) Hinge sliding

Figure 2. Undesirable modes of behaviour for seismically loaded monolithic cantilever structural walls in the post-elastic range $[10,11]$. 
In the case of cantilever structural walls there are a range of possible undesirable modes of behaviour. Overstrength of the wall in flexure could cause failure modes in either diagonal tension shear, sliding shear or hinge sliding (see Fig. 2b, c and d) which have limited ductility.

\subsection{Contributions to flexural strength}

The reasons for overstrength in flexure in some regions of the structure, leading to flexural yielding or shear failure in other regions, are many and include:

- Variations in the actual steel and concrete strength from the specified characteristic strengths throughout the structure.

- Cross sectional sizes larger than assumed.

- Additional reinforcement placed in members for construction purposes or to satisfy minimum reinforcement requirements or to satisfy available bar sizes, and unaccounted for in the design calculations.

- Use of strength reduction factors $\phi$ or material factors. in the design of cross sections.

- More critical loading cases for the design of some sections for gravity and wind loads.

- Participation of non-structural elements.

Some of these contributions to overstrength of regions of structures can be reasonably accurately predicted. For example, the fluctuations of the steel and concrete overstrength above the characteristic strengths can be estimated.

In practice the actual yield strength of the reinforcing steel will normally exceed the lower characteristic yield strength used in design. Also in the plastic hinge regions of ductile reinforced concrete structures during a major earthquake the longitudinal reinforcement may reach strains which are many times the strain at first yield and a further increase in steel stress due to strain hardening may occur. The maximum likely flexural strength at the plastic hinges is referred to as the flexural overstrength, which should be established by thorough statistical analyses of the stress-strain properties of the steel. Standards for steel, reinforcement need to specify the allowable range of actual steel yield strengths and ultimate strengths, for example [12]. In New Zealand Andriano and Park [13] found by statistical analysis that the flexural overstrength at beams reinforced by New Zealand manufactured Grade 300 and 430 reinforcing steel should be taken as $1.25 \mathrm{M}_{n}$ where $\mathrm{M}_{\mathrm{n}}$ is the nominal flexural strength of the section calculated using the lower characteristics (5 percentile value) yield strength of the steel reinforcement. A similar analysis is currently being undertaken in New Zealand to determine the flexural overstrength factor for when Grade 500 reinforcing steel is used. A preliminary outcome is that for New Zealand manufactured Grade 500 steel the flexural strength factor should be 1.4.

It should be noted that the steel strain at the ultimate strength of the steel (that is, at the peak stress of the stress-strain curve) should be at least about $10 \%$, to ensure high available curvature ductility factors in beams. It is of concern that reinforcing steels with much lower strains at the ultimate strength of the steel have been used in some countries in seismic regions.

The confinement of concrete by transverse reinforcement will also increase its compressive strength and can result in a significant increase in the flexural strength of columns [14].

Slab participation in the flexural behaviour of beams is important in the negative moment regions since the slab reinforcement can add significantly to the flexure strength. For example, the negative moment flexural strength of a Tbeam when slab reinforcement is included in addition to those bars placed within the web width of the beam can be in the order of 1.3 times the flexural strength calculated including only those bars within the web width of the beam [15]. The effect of strength reduction factors ( $\phi$ used in North American and New Zealand codes) or material factors ( $\gamma_{\mathrm{c}}$ and $\gamma_{\mathrm{s}}$ used in Europe) can be calculated. For instance, if the strength reduction factor for flexure is $\phi=0.85$, the nominal flexural strength is equal to the design flexural strength multiplied by $1 / \phi=1 / 0.85=1.18$.

The other contributions to overstrength listed above are more difficult to quantify. However, it is apparent that the actual flexural strength of regions of reinforced concrete structures could easily be 50 to $100 \%$ greater than the design flexural strengths of those regions.

In New Zealand in the late 1960 s and the 1970s it was realised that the possible effects of overstrength in flexure of some regions of the structure need to be carefully considered in seismic design to ensure that undesirable failure modes do not occur during severe earthquakes. For this reason the design approach termed capacity design was developed. This basis of the capacity design approach was first described in a paper by Hollings [16]. The method was developed by discussion groups of the New Zealand National Society for Earthquake Engineering and by Park and Paulay [10]. The capacity design approach was first recommended by the standard for general structural design in 1976 and by the New Zealand concrete design standard in 1982. A recent account of the capacity design approach is given by Paulay and Priestley [17].

\subsection{Assumed ductility in force-based design}

In force-based seismic design the horizontal equivalent static design seismic forces are obtained from the elastic response acceleration spectrum for the design earthquake factored down by a reduction factor which is a function of the period of vibration of the structure in the elastic range and the achievable displacement (structural) ductility factor, $\mu$. The displacement (structural) ductility factor is defined as $\Delta_{\max } / \Delta_{y}$, where $\Delta_{\max }$ is the maximum horizontal displacement imposed on the structure during the design earthquake, generally at the point of action of the resultant horizontal seismic force, and $\Delta_{\mathrm{y}}$ is the horizontal displacement at that point of the structure at first yield of the structure. According to the New Zealand design standards $[4,5]$ structures resisting earthquakes may be designed either as ductile structures, or as structures of limited ductility, or as elastically responding structures. For ductile reinforced 
concrete structures $\mu=5$ or 6 is used, for structures of limited ductility $\mu=2$ or 3 is used, and for elastically responding structures $\mu=1.25$ is used. It should be noted that drift limitations may limit the displacement ductility factor which can be used in design.

New Zealand design standards $[4,5]$ require that for the seismic design of ductile structures and of structures of limited ductility the design strengths of members required by force-based design be adjusted according to the capacity design approach.

\subsection{The capacity design approach}

The aim of the capacity design approach is to ensure that during an earthquake yielding of the structure will occur only in a chosen desirable manner. This is achieved by designing the structure so that it has a suitable hierarchy of member strength.

In the capacity design the structures appropriate regions of the lateral earthquake force resisting structural system are chosen and suitably designed and detailed for adequate strength and ductility for the design earthquake. All other regions of the structural system, and other possible failure modes, are then provided with sufficient strength to ensure that the chosen means for achieving ductility can be maintained throughout the post-elastic deformations that may occur.
For moment resisting frames of buildings the best means of achieving ductile post-elastic deformations is by flexural yielding at selected plastic hinge position, since with proper design and detailing the plastic hinges can be made adequately ductile $[4,10,17,18]$

Significant post-elastic deformations due to shear or bond mechanisms are to be avoided since with cyclic loading they lead to severe degradation of strength and stiffness and to reduced energy dissipation due to pinched load-displacement hysteresis loops. Post-elastic deformations due to flexural yielding at well designed plastic hinge regions result in stable load-displacement hysteresis loops without significant degradation of strength, stiffness and energy dissipation.

The preferred mechanism for moment resisting frames is a beam sidesway mechanism (see Fig. 3a). A beam sidesway mechanism occurs as a result of strong column-weak beam design $[4,10]$. The ductility demand at the plastic hinges in the beams and at the column bases is moderate for this mechanism and can easily be provided in design. A column sidesway mechanism should not be permitted (except for the exceptions given below) since it can make very large demands on the ductility at the plastic hinges in the columns of the critical storey [10]. Column sidesway mechanisms (see Fig. 1b) (soft storeys) have often led to the collapse of buildings during earthquakes. The critical soft storey has generally been the bottom storey but may be an intermediate storey up the height of the frame.

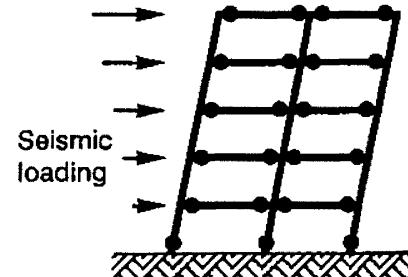

(a) Beam sidesway mechanism

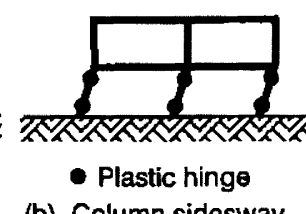

(b) Column sidesway mechanism

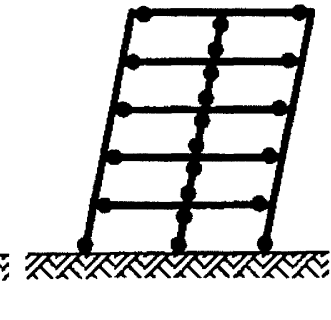

(c) Mixed sidesway mechanism of a gravity load dominated frame

Figure 3. Desirable mechanisms of post-elastic deformation of monolithic moment resisting frames during severe seismic loading according to the New Zealand concrete design standard [4].

The New Zealand concrete design standard [4] has only two exceptions to the requirement of the strong-column weakbeam design approach for ductile frames: (1) For one or two storey buildings (see Fig. 3b), or in the top storey of a multistorey building, column sidesway mechanisms are permitted (that is, a strong beam-weak column approach), since the curvature ductility demand at the plastic hinges in the columns in such cases is not high, and (2) If for tall frames strong-column weak beam design is impracticable (for example, in areas of low seismicity where gravity loading dominates the design, and/or if the beams have long spans) some columns may be permitted to form plastic hinges at the top and bottom simultaneously providing that the other columns (typically the exterior columns) remain in the elastic range and prevent a soft storey failure (see the mixed sidesway mechanism of Fig. 3c). In such case the permitted structure ductility factor used in design may need to be adjusted.

It should be appreciated that the mechanisms of Figure 3 are idealised in that they involve possible post-elastic behaviour obtained from static "push-over" analysis with the frame subjected to code type equivalent horizontal static seismic forces. The actual dynamic situation is different, due mainly to the effects of higher modes of vibration of the structure. For example, the curvature ductility demand at the plastic hinges in the beams in the lower region of the frame of a beam sidesway mechanism may be greater than in the upper region. However, considerations such as those shown in Figure 3 can be regarded as providing the designer with a reasonable feel for the situation. Non-linear dynamic analyses indicate that mechanisms such as those shown in Fig. 3 do form. 
4.5 Capacity design actions recommended in New Zealand for strong column-weak beam design of ductile moment resisting frames

(a) Design shear forces in beams:

The design shear forces in beams should be determined by a capacity design procedure for when the flexural overstrength is reached at the most probable plastic hinge locations within the span and the design gravity load is present. The flexural overstrength capacities are calculated from $1.25 \mathrm{M}_{\mathrm{n}}$ where $\mathrm{M}_{\mathrm{n}}$ is the nominal flexural strength of the section including an allowance for the slab reinforcement in negative moment regions. As a result of tests by Cheung et al [15] the New Zealand concrete design standard [4] recommends that the slab width, within which effectively anchored longitudinal slab reinforcement shall be considered to contribute to the negative moment flexural strength of the beam, in addition to those bars placed within the web width of the beam, for interior spans shall be defined as one-quarter of the span of the beam extending each side of the beam from the centre of the beam section but not greater than the width to the centre of the slab panels each side. A strength reduction factor $\phi=1$ is used for the design of the section for shear when the design shear force is found using the capacity design procedure [4].

(b) Design bending moments in columns:

The capacity design rules for protecting the columns of tall moment resisting frames, by ensuring that as far as possible strong-column-weak beam behaviour occurs, were first introduced in the New Zealand concrete design standard in 1982 and have remained practically the same in the 1995 standard [4].

The procedure [4] for determining the design bending moments in the columns is illustrated in Figure 4. The design bending moment for the column at the centre of the beam-column joint is:

$M_{c o l}^{\star}=\omega \phi_{0} M_{e}$

where $M_{e}$ is the column bending moment at the centre of the beam-centre joint derived by elastic structural analysis for the equivalent static design forces; $\phi_{\mathrm{o}}$ is the ratio of the sum of the flexural overstrength capacities of the beams at the joint as detailed to the sum of the bending moments of the beams at the joint resulting from the equivalent static design seismic forces $1.25 / 0.85=1.47$, where $1.25=$ overstrength factor applied to the nominal flexural strength and $0.85=$ strength reduction factor; $\omega$ is a factor allowing for higher modes of vibration and bidirectional seismic force effects, given for one-way frames as $\omega=0.6 \mathrm{~T}+$ 0.85 but not less than 1.3 or more than 1.8 , and for twoway frames as $\omega=0.5 \mathrm{~T}+1.1$ but not less than 1.5 or more than 1.9, where $\mathrm{T}=$ fundamental period of vibration of the structure.

As shown in Figure 4, the critical column section is assumed to be at the top and bottom of the beams and accordingly the centreline column bending moment $\omega \phi_{\mathrm{o}} \mathrm{M}_{\mathrm{e}}$ is reduced by $0.3 \mathrm{~h}_{\mathrm{b}} \mathrm{V}_{\text {col }}^{*}$, which is based on an estimated gradient of the column bending moment diagram, where $h_{b}=$ beam depth and $V_{e}^{*}=$ column shear force.

The recommended amplification of column bending moments by this procedure can be significant, the combined factor $\omega \phi_{0}$ being at least 1.91 for one-way frames and at least 2.21 for two-way frames.

Note that for two-way frames the columns are designed for uniaxial bending only, since $\omega$ includes some moment amplification for the effect of biaxial bending. The above values of $\omega$ are based on dynamic analyses and judgement [19].

(c) Design axial loads in columns:

The design axial loads in the column $\mathrm{N}_{\text {col }}^{*}$ to be used with $\omega \phi_{o} M_{e}-0.3 h_{b} V_{e}^{*}$ in the design of the column sections in New Zealand [4] is found by summing all the shear forces applied at

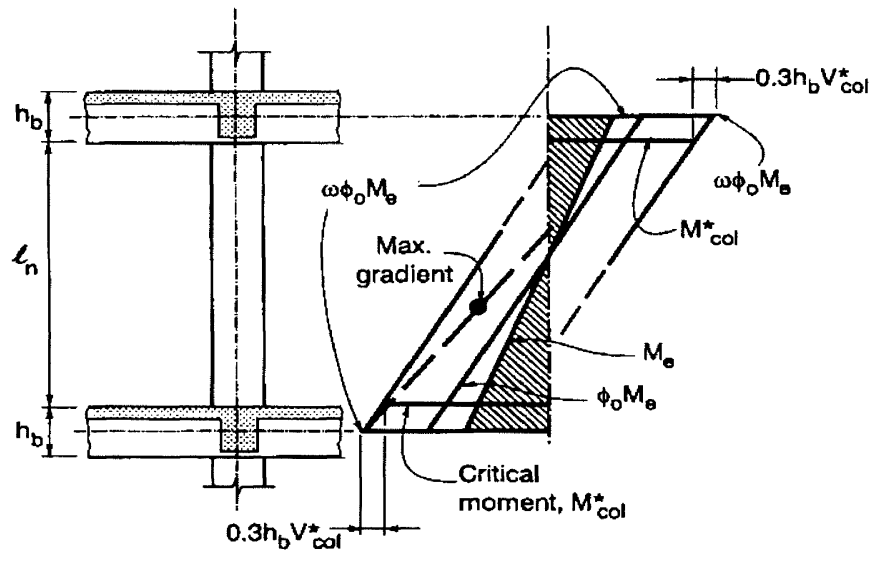

Figure 4. Stages of amplification of column bending moments in capacity design [11]. 
the column faces by the gravity loads on the beams and the moment induced shear forces from the beam plastic hinge moments acting in the two directions concurrently. An adjustment in the moment induced shears is allowed [4] to take into account the probability that not all beam plastic hinges reach their flexural overstrength simultaneously up the height of the frame. A strength reduction factor $\phi=1.0$ is used for the section design when the column design actions are found using this capacity design procedure [4].

(d) Design shear forces in columns:

The New Zealand procedure [4] for determining the design shear forces in the columns above the first storey of the building, acting separately in each of the two principal directions are taken for a one-way frame as $\mathrm{V}_{\text {col }}^{*}=1.3 \phi_{\mathrm{o}} \mathrm{V}_{\mathrm{e}}$ and for a two-way frame as $\mathrm{V}_{\text {col }}^{*}$ $=1.6 \phi_{0} V_{e}$ where $\phi_{0}$ is the beam overstrength factor defined as in Section 4.5(b) and $V_{e}$ is the column shear force derived for the equivalent static design seismic forces at the ultimate limit state. These forces were estimated from probable critical moment gradients along columns [19]. The larger value for two-way frames is to include the effect of concurrent seismic loading acting along both principal axes of the building simultaneously. For the column of the first storey the design shear forces are taken as $V_{\text {col }}^{\star}=\left(M_{o, \text { col, bottom }}+\right.$ $\left.\mathrm{M}_{\mathrm{o}, \text { col, top }}\right) / \ell_{\mathrm{n}}$, where $\mathrm{M}_{\mathrm{o} \text {, col, bottom }}$ and $\mathrm{M}_{\mathrm{o} \text {, col, top }}$ are the flexural overstrength capacities of the bottom and top critical plastic hinge sections of the columns, respectively, and $\ell_{n}=$ clear length of column between beams. The flexural overstrength column capacities should include the effects of both the steel and the concrete overstrengths, obtained by multiplying the nominal flexural strength by a factor in the range 1.25 to 2.0 depending on the axial load ratio $\mathrm{N}^{*} / \mathrm{f}_{\mathrm{c}}^{\prime} \mathrm{A}_{\mathrm{g}}$ and the actual reinforcement contents [14]. A strength reduction factor $\phi=1$ is used for the design of the section for the shear forces found this way.

(e) Design shear forces in beam-column joints:

The design shear forces in beam-column joints are calculated using the overstrength steel forces and the design shear forces for the members at overstrength. The calculation of the design horizontal joint shear force involves the determination of the net horizontal force above or below a horizontal plane passing through the centre of the joint core[4]. Similarly, the design vertical joint shear force can be calculated from the net vertical force to one side or other of a vertical plane passing through the centre of the joint core.

\subsection{Capacity design actions recommended in New Zealand for strong column-weak beam design of moment resisting frames of limited ductility}

For moment resisting frames of limited ductility in order to ensure a beam sidesway mechanism with plastic hinges in the columns permitted only at the base of the frame and in the top storey, the capacity design procedure [4] to determine the column design actions takes account of possible beam overstrength, a general direction of seismic forces and magnification of column moments due to dynamic effects. However, the procedure is a relaxation of that used for ductile frames. The magnified column bending moments at the beam centre line (to be reduced for moment gradient to obtain the value at the critical sections) are taken as $1.1 \phi_{0} M_{e}$ for one-way frames and $1.3 \phi_{o} \mathrm{M}_{\mathrm{e}}$ for two-way frames. The shear forces in the upper columns are taken as $1.1 \phi_{o} V_{e}$ for one-way frames and $1.3 \phi_{\mathrm{o}} \mathrm{V}_{\mathrm{e}}$ for two-way frames, where the notation is as in Sections 4.5. The structural ductility factor $\mu$ of such frames should be taken as 3 .

\subsection{Comparison of design actions recommended for moment resisting frames by other seismic design codes of international standing}

A comparison of major national seismic design codes and guidelines has been conducted by Booth et al [20]. The codes considered were Eurocode 8 [1], the guidelines of the Architectural Institute of Japan [2], United States codes (the building code of the American Concrete Institute [3] and the Uniform Building Code [21]), and the New Zealand standard [4]. It was found that all of those codes and guidelines recognise capacity design, although to varying degrees of clarity, and the degree to which capacity design is incorporated in each code varies significantly.

Of particular note is the difference in opinion internationally with regard to the multiplier $\omega \phi_{0}$ used to find the design bending moment $\mathrm{M}_{\mathrm{col}}$ for a column from the column bending moment $\mathrm{M}_{\mathrm{e}}$ found by elastic structural analysis for the equivalent static seismic forces (see Section 4.5(b)). According to the New Zealand standard [4] for strong column-weak beam design $\omega$ varies between 1.3 and 1.9 for one-way and two-way frames and the combined factor $\omega \phi_{0}$ is at least 1.9 for one-way frames and 2.2 for two-way frames. However, Pinto et al [22] as a result of the dynamic analysis of one-way four and eight storey symmetrical moment resisting frames have concluded that $\omega=1.35$ may be high enough. Also Panagiotakis et al [23] have concluded that somewhat smaller values for $\omega$ than specified in the New Zealand standard do not lead to soft storey formation.

By comparison the building code of the American Concrete Institute [3] requires that the sum of the nominal flexural strengths of the columns at beam-column joints exceed the sum of the nominal flexural strength of the beams there by at least $20 \%$. Also, Eurocode 8[1] requires that for frames of two or more storeys the sum of the design values of the flexural strengths of the columns at beam-column joints exceed the sum of the design values of the flexural strengths of the beam there by at least $30 \%$.

Whether the amplification should be applied to the column moment at the joint found by elastic structural analysis or to the sum of the column flexural strengths at each joint is also an issue. In the opinion of the author amplifications applied to column flexural strengths at joints on a joint by joint basis will not necessarily prevent column sidesway mechanisms.

Recently Dooley and Braci [24] have studied three and six storey moment resisting plane frames subjected to seismic excitation using non-linear time-history dynamic analysis. 
Various column-to-beam flexural strength ratios were considered. For a column-to-beam flexural strength ratio of 1.2 it was concluded that the probability of the formation of a column sidesway mechanism was approximately $90 \%$. Their results indicate that the minimum column-to-beam flexural strength ratio should be approximately 2.0 to have a significant probability of avoiding column sidesway mechanisms. This issue is still controversial, but this latest evidence [24] does indicate that the New Zealand recommended values may be in the right order.

These differences in the capacity design factors for the determination of the design bending moments of columns need to be resolved.

\subsection{Capacity design of reinforced concrete structural walls}

The preferred mechanism for cantilever structural walls involves a plastic hinge at the base. The design shear force should be that for when the flexural overstrength is reached at the base of the wall.
For dual systems (combined moment resisting frames and structural walls) the deformation of the frames will be controlled by the much stiffer walls.

Normally the frames are much more flexible than the walls and hence the plastic hinging in the frames will be very limited. In cases where the frames are much more flexible than the walls the frames may remain in the elastic range and then can be designed for nominal ductility.

\subsection{Implementation of capacity design by codes}

Capacity design offers the advantages of a rational design procedure and a greater reliability of seismic performance. The approach has been implemented to varying degrees in design codes and guidelines throughout the world. Table 1 lists the specific capacity design measures that need to be implemented in seismic design codes and those implemented in New Zealand and the USA [25].

Codes not based on capacity design do not provide a consistent and understood level of seismic protection for all structural systems.

Table 1. Capacity design practices [25] currently required by seismic design codes for concrete buildings in New Zealand [4] and the USA [3]

\begin{tabular}{|c|c|c|}
\hline & $\begin{array}{c}\text { New } \\
\text { Zealand } \\
\end{array}$ & USA \\
\hline \multicolumn{3}{|l|}{ Global behavior } \\
\hline Explicit identification of nonlinear mechanism of response. & Yes & No \\
\hline Story mechanisms prevented. & Yes & No \\
\hline Collectors designed for mechanism overstrength. & Yes & No \\
\hline $\begin{array}{l}\text { Diaphragm shears and moment strength taken from } \\
\text { mechanism overstrength. }\end{array}$ & Yes & No \\
\hline $\begin{array}{l}\text { Foundations designed for mechanism strength, or } \\
\text { foundation-rocking mechanism explicitly identified. }\end{array}$ & Yes & No \\
\hline \multicolumn{3}{|l|}{ Ductile moment resisting frame design } \\
\hline Beam shear strength exceeds beam flexural overstrength. & Yes & Yes \\
\hline $\begin{array}{l}\text { Column shear strength exceeds column flexural } \\
\text { overstrength. }\end{array}$ & Yes & Yes \\
\hline $\begin{array}{l}\text { Inelastic dynamic amplification of column moments and } \\
\text { shears, including bi-directional seismic effects. }\end{array}$ & Yes & No \\
\hline $\begin{array}{l}\text { Shear force in beam-column joints taken from overstrength } \\
\text { of beam plastic hinging. }\end{array}$ & Yes & Yes \\
\hline $\begin{array}{l}\text { Bond strength of bars passing through beam-column joints } \\
\text { exceeds flexural overstrength. }\end{array}$ & Yes & No \\
\hline $\begin{array}{l}\text { Lap splices permitted at column ends if column end does } \\
\text { not yield. }\end{array}$ & Yes & No \\
\hline $\begin{array}{l}\text { Tension-shift effect considered for length of confined region } \\
\text { of columns. }\end{array}$ & Yes & Yes \\
\hline \multicolumn{3}{|l|}{ Ductile structural wall design } \\
\hline Wall shear strength exceeds flexural overstrength. & Yes & No \\
\hline Inelastic dynamic amplification effects for wall shear. & Yes & No \\
\hline $\begin{array}{l}\text { Tension-shift and higher-mode effects considered for } \\
\text { curtailment of wall longitudinal reinforcement. }\end{array}$ & Yes & No \\
\hline Sliding shear failure prevented. & Yes & No \\
\hline
\end{tabular}




\section{5}

\section{THE USE OF HIGH STRENGTH MATERIALS}

\subsection{Introduction}

High strength concrete (compressive strength greater than about 60-70 $\mathrm{MPa}$ ) and high strength non-prestressed steel reinforcement (yield strength greater than about $500 \mathrm{MPa}$ ) are available in many parts of the world. Seismic design codes permit their use to varying degrees.

\subsection{High strength concrete}

High strength concrete can be used to advantage in the design of buildings since it leads to columns which can carry higher loads for the same size column cross section, or to smaller column cross sections for the same size loads. Other reasons for the use of high strength concrete include its high elastic modulus, thus reducing deflections, its low creep deformations, and its improved durability.

Figure 5 shows examples of the stress-strain curves for high and normal strength concrete in compression. High strength concrete is more brittle than normal strength concrete and when high strength concrete is used in flexural members the shape of the compressive stress block used in design needs to be modified to account for the sharper fall off of stress after peak stress [4]. Also in high strength concrete columns designed for seismic resisting structures large quantities of transverse confining reinforcement are required to achieve ductile behaviour [26]. In addition, high strength concrete exhibits less internal microcracking than normal strength concrete for a given imposed axial compressive strain near its compressive strength. The lower lateral expansion of high strength concrete means that confinement from transverse reinforcement may be less effective. For example, the stress in the transverse reinforcement at the peak load of a high strength concrete column may be less than the yield strength if high strength transverse reinforcement is used. Also the faces of cracks in high strength concrete are often smoother than in normal strength concrete because of possible fracture of aggregate. Hence shear resisting mechanisms involving aggregate interlock may not be so effective in high strength concrete.

Hence some special code provisions for high strength concrete are required. For example the New Zealand concrete design standard [4] recommends that the specified compressive cylinder strength for ductile and limited ductile elements in seismic design shall not exceed $70 \mathrm{MPa}$. This limitation is mainly because of the difficulty in providing sufficient transverse reinforcement to confine very high strength concrete to make it adequately ductile.

In the ACI building code [3] no maximum concrete compressive cylinder strength is specified unless restricted by a specific code provision.

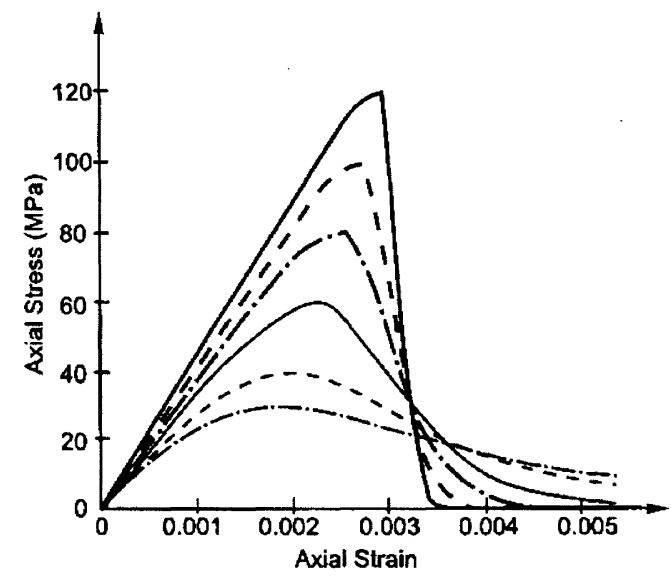

Figure 5. Stress-Strain Curves for Unconfined Normal and High Strength Concrete in Compression.

\subsection{High strength steel reinforcement}

(a) General:

Figure 6 shows typical stress-strain curves for New Zealand manufactured Grades 300, 430 and 500 reinforcing steel and two examples of Japanese manufactured very high strength reinforcing steel. The steel grade in New Zealand refers to the characteristic ( 5 percentile value) of the yield strength in $\mathrm{MPa}$.

(b) Design yield strength of high strength longitudinal reinforcing steel:
For longitudinal reinforcement the New Zealand standard for concrete design [4] requires that the lower characteristic yield strength used in design be not greater than $500 \mathrm{MPa}$. The commentary of the standard [4] states that the main reason for this limitation is to restrict the width of flexural cracks at the service loads. Other reasons are the difficulty of anchoring high strength reinforcement, particularly in beamcolumn joints (see Section 7) and the reduced useable displacement ductility factor when the reinforcement is of high strength steel $[9,27,28]$. 


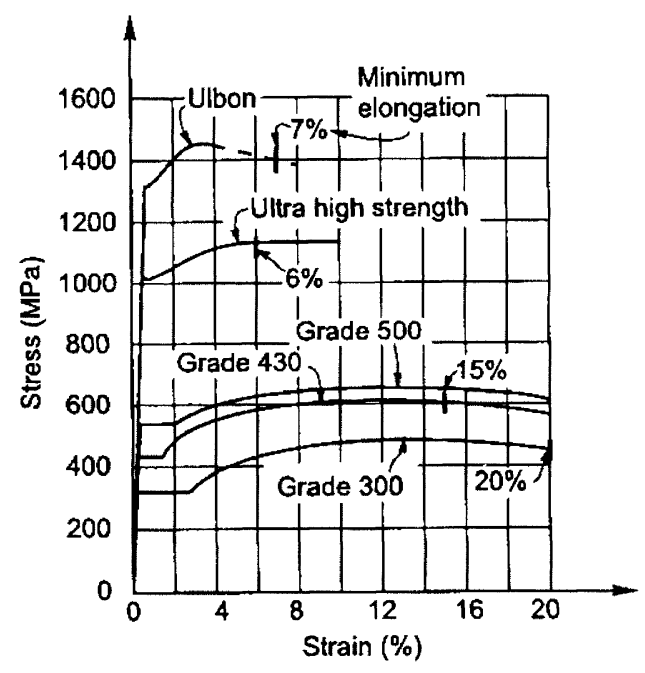

Figure 6. Typical stress-strain curves for New Zealand Grades 300, 430 and 500 reinforcing steel and Japanese very high strength reinforcing steel.

The reduced useable displacement ductility factor $\mu$ is the result of the reduced curvature at first yield $\phi_{y}$ of members reinforced by high strength reinforcement. Note that $\phi_{y}=$ $\varepsilon_{\mathrm{y}} / \mathrm{d}$-c where $\varepsilon_{\mathrm{y}}$ is the strain in the steel at first yield, $\mathrm{d}$ is the effective depth of the member and $\mathrm{c}$ is the neutral axis depth [10]. The displacement at first yield $\Delta_{y}$ is directly proportional to $\phi_{\mathrm{y}}$ and hence to the steel grade.

For example since $\varepsilon_{y}$ is directly proportional to the yield strength of the steel it is evident that when Grade 500 steel is used $\Delta_{\mathrm{y}}$ will be $500 / 300=1.67$ times the $\Delta_{\mathrm{y}}$ associated with Grade 300 steel. Hence in that case if the maximum displacement $\Delta_{\max }$ of the structure in design is limited by the maximum storey drift permitted by the code, the useable displacement ductility factor $\Delta_{\max } / \Delta_{\mathrm{y}}$ is reduced to $1 / 1.67$ times that associated with Grade 300 steel. For example consider a moment resisting frame with a beam yielding mechanism and beams designed using Grade 300 steel reinforcement using a displacement ductility factor of 6 . Let the frame be subjected to the maximum storey drift permitted by the code at the ultimate limit state. If the reinforcement is changed to Grade 500 steel then the useable displacement ductility factor will need to be reduced to $6 \times 1 / 1.67=3.6$ leading to an increase in the seismic design forces. Hence a reduction in the longitudinal steel area resulting from the use of Grade 500 steel may not be achieved. Designers may prefer to use the more easily anchored Grade 300 reinforcement for beams. However, there are advantages in using higher strength reinforcement in columns.

(c) Design yield strength of high strength transverse reinforcing steel:

For the design of transverse reinforcement for shear New Zealand concrete design standard [4] requires that the design yield strength not be taken greater than $500 \mathrm{MPa}$. The commentary [4] states that this limitation is to restrict the width of diagonal tension cracks in the concrete at the service loads.

However, in the design of transverse reinforcement to confine the concrete and to provide restraint against lateral buckling of longitudinal reinforcement New Zealand standard [4] permits a yield strength as high as $800 \mathrm{MPa}$ to be used in design calculations.

This means that in practice a high strength transverse reinforcement with a lower characteristic yield strength equal to or greater than $800 \mathrm{MPa}$ can be used providing that the value of the yield strength used in design does not exceed $500 \mathrm{MPa}$ for shear calculations and $800 \mathrm{MPa}$ for concrete confinement and longitudinal bar lateral restraint calculations. The reason why the design yield strength has been limited to $800 \mathrm{MPa}$ in this case is the lower dilation of high strength concrete and the higher longitudinal strains required before substantial stresses can be developed in transverse reinforcement confining high strength concrete, as observed in tests conducted on reinforced concrete columns by Li et al [26].

\section{DETAILING OF REINFORCED CONCRETE COLUMNS FOR DUCTILITY}

\subsection{Transverse reinforcement for shear resistance, confinement of concrete and for preventing buckling of longitudinal reinforcement}

The most important design consideration for ensuring that the plastic hinge regions of reinforced concrete members of moment resisting frames are ductile is the provision of adequate longitudinal compression reinforcement as well as tension reinforcement, and the provision of transverse reinforcement in the form or rectangular hoops with or without cross ties, or circular hoops or spirals (see Fig. 7). This transverse reinforcement is needed to act as shear reinforcement, to confine and hence to enhance the ductility of the compressed concrete, and to prevent premature buckling of the compressed longitudinal reinforcement. According to the New Zealand concrete design standard [4] in order to confine the compressed concrete of columns in potential plastic hinge regions the centre-to-centre spacing of transverse reinforcement along the member should not exceed one-quarter of the least lateral dimension of the cross 
section or $200 \mathrm{~mm}$, whichever is greater. Also, the centre-tocentre spacing of transverse reinforcement along the member in potential plastic hinge regions of beams and columns should not exceed six longitudinal bar diameters in order to control bar buckling [4]. The amount of transverse reinforcement necessary in columns to ensure adequate available ductility to match the imposed ductility can be calculated by moment-curvature analysis incorporating the stress-strain relations for confined concrete $[10,14,29-31]$.

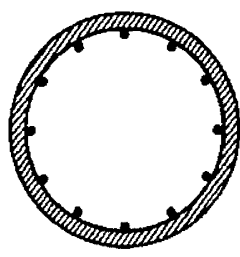

(a) Circular hoops or spiral

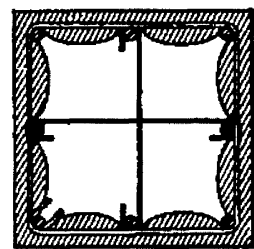

(b) Rectangular hoops with cross ties

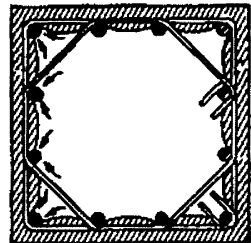

(c) Overlapping rectangular hoops

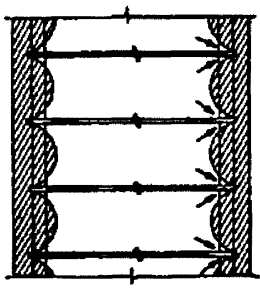

(d) Confinement by transverse bars

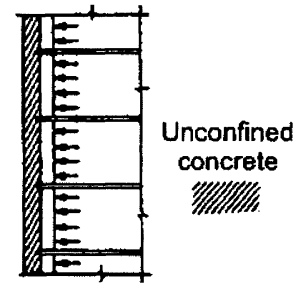

(e) Confinement by longitudinal bars

Figure 7. Reinforcement in a column for shear resistance, concrete confinement and prevention of premature buckling of longitudinal bars.

The equation for the amount of transverse reinforcement required to confine the compressed concrete of reinforced concrete columns in potential plastic hinge regions recommended by the New Zealand concrete design standard [4] was derived by Watson et al [31]. The amount is a function of the axial load level $N * / f_{c}^{\prime} A_{g}$, where $N^{*}$ is the axial compressive load on the column, $f_{c}^{\prime}$ is the concrete compressive cylinder strength and $\mathrm{A}_{\mathrm{g}}$ is the area of the column. According to the New Zealand equation the required amount of confining reinforcement increases with axial load level. Heavily loaded columns need more confining reinforcement because greater neutral axis depth $c$ means that a greater extreme fibre concrete compressive strain $\varepsilon_{\mathfrak{c}}$, and hence a greater amount of confinement is needed, to achieve a given ultimate curvature $\phi_{u}=\varepsilon_{\mathrm{c}} / \mathrm{c}$.

An example of the quantities of transverse reinforcement required by the New Zealand concrete design standard [4] for confinement of concrete in the potential plastic hinge regions of columns when a curvature ductility factor $\phi_{\mathrm{u}} / \phi_{\mathrm{y}}$ of 20 is required is shown in Figure 8, where $\phi_{\mathrm{u}}$ is the ultimate curvature and $\phi_{\mathrm{y}}$ is the curvature at first yield. Note that the requirement for concrete confinement in the New Zealand standard governs at higher axial loads and the requirement for preventing buckling of the longitudinal reinforcement governs at lower axial loads.

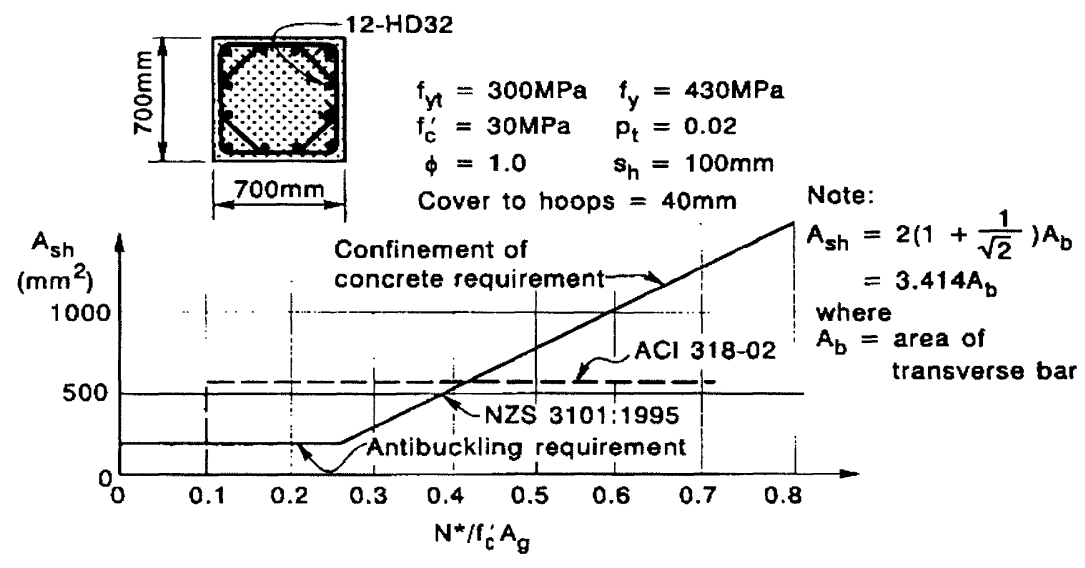

Figure 8. Example of transverse reinforcement required in a ductile column. 
Also in some cases transverse reinforcement required for shear resistance may govern. By comparison the ACI building code [3] amount, required for confinement, as shown in the example of Fig. 8, is a single constant value regardless of the axial load level. The EC8 [1] requirements are also dependent on the axial load level and generally lead to greater quantities of transverse reinforcement than the New Zealand requirements [20].

\subsection{Length of end region of column to be confined}

The confined length of column adjacent to the section of maximum bending moment (see Fig. 9) needs to be sufficiently long to extend over the region of major plastic curvature and to ensure that the higher flexural strength of the column in the confined region does not lead to flexural failure of the column in the adjacent less confined region.
The second requirement is particularly important for normal strength concrete columns with high axial compression, since for such columns the flexural strength is markedly increased by confinement of the concrete, Zahn et al [14], Watson et al $[31,32]$.

Figure 9 shows the distribution of bending moments for a cantilever column due to an imposed lateral load at the top, and the flexural strengths of the confined and nominally confined regions of the column. To compensate for the effects of the spread of yielding due to possible diagonal tension cracking, the moment diagram is spread by $\mathrm{h} / 2$ along the member, where $h=$ column depth. The length of the region that needs to be confined $P_{c}$ can be estimated knowing the enhanced flexural strength $\mathrm{M}_{\mathrm{i}}$ in the confined region and the conventionally calculated flexural strength $\mathrm{M}_{\text {code }}$ outside the confined region.

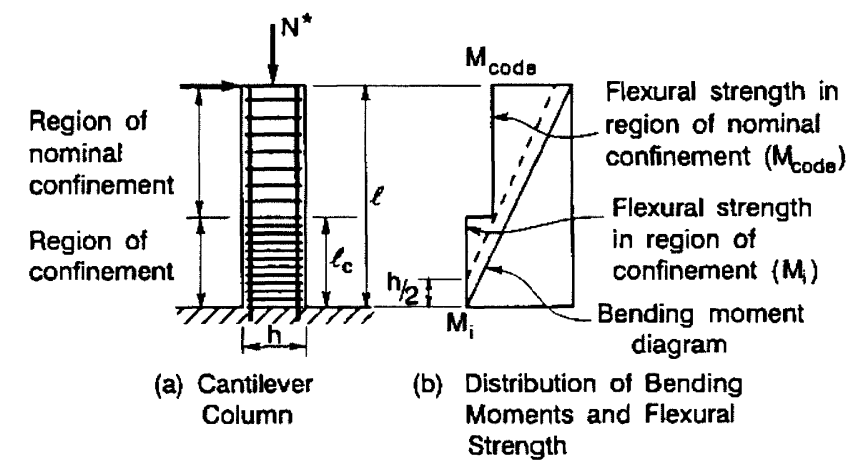

Figure 9. Determination of the length of the confined end region of columns.

An analysis by Watson et al [32] of the test results from the columns subjected to simulated seismic loading at the University of Canterbury since the late 1970s, resulted in the current requirements in the New Zealand concrete design standard [4], which are: (1) the confined length $P_{c}$ for low axial load levels when $N^{*}<0.25 f_{c}^{\prime} A_{g}$ is taken to be the greater of $h$ or where the moment exceeds 0.8 of the adjacent end moment. $\mathrm{P}_{\mathrm{c}}$ for high axial load levels with $\mathrm{N}^{*}>0.5$ $f_{C}^{\prime} A_{g}$ is taken to be the greater of $3 h$ or where the moment exceeds 0.6 of the adjacent end moment. An intermediate value of $P_{c}$ is taken for axial load levels in between. In the above $N^{*}$ is the axial compressive load on the column, $f_{c}^{\prime}$ is the concrete compressive cylinder strength, $\mathrm{A}_{\mathrm{g}}$ is the area of the column and $\mathrm{h}$ is the overall depth of the column. Hence typically the confined length $P_{c}$ varies between $h$ and $3 h$.

By comparison the other national standards recommend shorter confined lengths than the New Zealand standard.

Outside the potential plastic hinge region (the confined length) the quantity of transverse reinforcement required by the New Zealand concrete design standard [4] is taken as not less than $70 \%$ of that placed in the potential plastic hinge region.

\section{7 \\ DESIGN OF REINFORCED CONCRETE BEAM-COLUMN JOINTS}

\subsection{Introduction}

Seismic design standards in the 1960s and before gave no attention to detailing beam-column joints of moment resisting reinforced concrete frames. With improvement in the detailing of the adjacent beams and columns the consequences of the lack of attention to the shear strength of beam-column joints has been demonstrated by severe diagonal tension cracking in that region observed in many laboratory tests and in many structures during earthquakes. The consequence of that diagonal tension cracking is a significant increase in flexibility of the frame, and joint shear failure that has often led to collapse of the structure due to Pdelta effects or loss of gravity load carrying capacity through the joint when columns have carried heavy axial compressive loads.

However, seismic design codes differ significantly in their design approaches to beam-column joints, and this remains probably the most controversial aspect of the seismic design of reinforced concrete moment resisting frames at present [33]. 
About 20 years ago in an attempt to resolve the difference between codes a collaborative USA/New Zealand/Japan/China research project was established involving a comparison of code approaches for beam-column joints and comparison of the results of simulated seismic load tests on reinforced concrete beam-column joint specimens designed according to those codes. Unfortunately the outcome of the research project was not a harmonization of the codes of the countries. Differences in the interpretation of the test data and in the definition of what could be designed as acceptable behaviour could not be resolved.

Major differences lie between the New Zealand and the US design provisions.

\subsection{Nominal horizontal joint shear forces}

Fig. 10(a) and (b) show the forces from beams and columns during an earthquake acting on an interior beam-column joint and the resulting crack pattern and bond forces after diagonal tension cracking initiates in the joint core.

The maximum design horizontal and vertical shear forces acting on the joint core can be calculated from the forces when the flexural overstrength of the adjacent plastic hinges are developed. The nominal horizontal joint shear stress is calculated from the horizontal joint shear force divided by the effective horizontal area of the joint which is normally the area of the column.

\subsection{Design approaches for shear}

(a) The New Zealand approach:

In the New Zealand concrete design standard [4] the joint shear forces are considered to be resisted by the contributions of the two mechanisms shown in Fig. 10c) and (d): One mechanism (Fig. 10(c)) consists of a single concrete diagonal compression strut which transfers both horizontal and vertical shear forces applied to the ends of the strut mainly by the compression forces in the concrete from the beams and columns. Also, some of the bond forces from the longitudinal bars passing through the joint are transferred to the ends of the strut. The second mechanism (Fig. 10(d)) is a truss mechanism consisting of a concrete diagonal compression field and the horizontal and vertical reinforcement in tension needed for equilibrium after diagonal tension cracking. The truss mechanism transfers mainly the shear induced in the joint core by the bond forces in the interior of the joint from the longitudinal bars passing through the joint. The New Zealand concrete design standard [4] gives equations for determining the amount of horizontal and vertical shear reinforcement required. Normally the horizontal shear reinforcement is in the form of rectangular hoops and cross ties or spirals, and the vertical shear reinforcement is already present in the form of intermediate longitudinal column bars in the side faces between the corner bars. The New Zealand standard [4] also requires that the quantity of horizontal joint reinforcement placed for shear should not be less than that required in the end regions of the column above and below the joint for column ductility.

The nominal horizontal joint shear stress is not permitted to exceed $0.2 f_{c}^{\prime}$ in order to prevent a diagonal compression failure.

(b) USA:

The design approach of the building code of the American Concrete Institute [3] is to require that the nominal horizontal joint shear stress does not exceed limiting values which depend on the degree of confinement of the joint core by beams entering the sides of the joint. The limiting nominal horizontal joint shear stresses are $1.7 \sqrt{\mathrm{f}_{\mathrm{c}}^{\prime}}$ MPa for joints confined on all four faces, $1.25 \sqrt{f_{c}^{\prime}}$ MPa or joints confined on three faces or on two opposite faces, and $1.0 \sqrt{f_{\mathrm{c}}^{\prime}} \mathrm{MPa}$ for other cases. The amount of horizontal reinforcement in the joint core (area of transverse steel divided by the spacing) is required not to be less than that given by equations for confinement in the adjacent ends of the columns specified by the ACI building code [3]. These equations are based on the consideration that the axial load compressive strength of the core of the column (ie, after spalling of the cover concrete) should at least equal the axial load compressive strength of the gross column section.

The US approach appears to the author to be an over simplification. The amount of transverse reinforced in the joint core is the same as the transverse reinforcement placed in the adjacent ends of the columns. The US approach is not based on a model of joint core behaviour and it ignores a number of variables such as column axial load level, the deterioration of joint confinement by beam plastic hinging due to bi-directional seismic loading and the need for vertical shear reinforcement.

(c) Europe and Japan:

In the design approach for joint shear in Europe [1] transverse reinforcement is provided in the joint to limit the maximum diagonal tensile stress of the concrete to the tensile strength of the concrete. Vertical reinforcement is also required to be present in the joint. On the other hand the Architectural Institute of Japan considers the joint shear strength not to be affected by the amount of transverse reinforcement in the joint. 


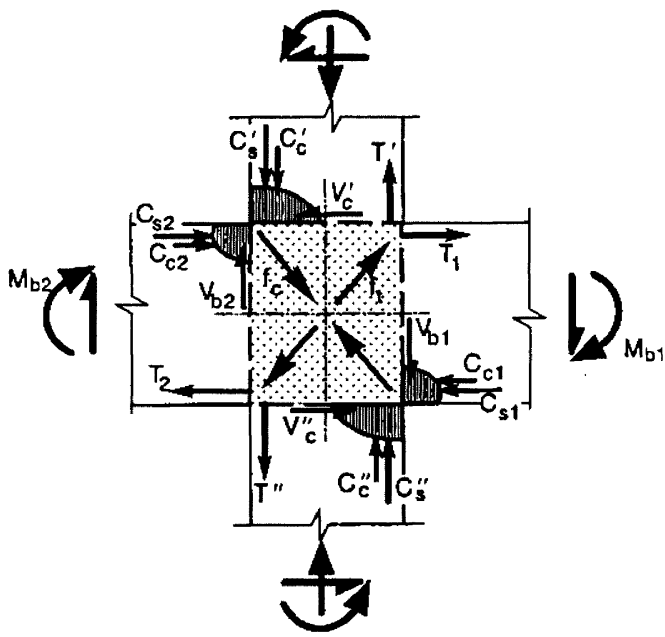

(a) Forces from beams and columns acting on the joint

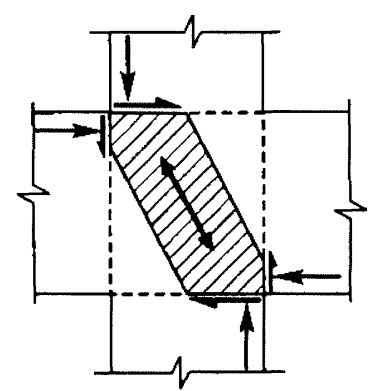

(c) Concrete diagonal strut mechanism. equlibrating concrete compression forces in beams and columns and some bond forces in the compression zones
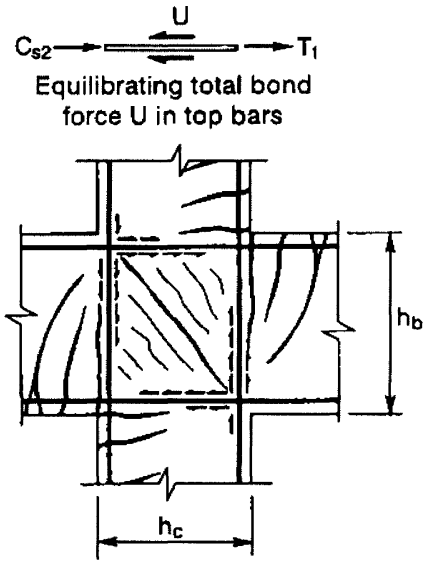

(b) Crack pattern and bond forces after diagonal tension cracking initiates in joint core

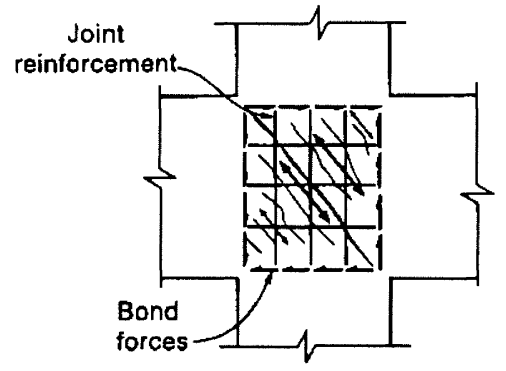

(d) Truss mechanism of concrete diagonal compression field and horizontal and vertical reinforcement needed for equilibrium after diagonal tension cracking

Figure 10. Forces acting on a reinforced concrete interior beam-column joint during an earthquake and the resulting cracking and mechanisms of force transfer assumed in New Zealand.

Hence there are considerable differences in the design procedures for transverse reinforcement in beam-column joints in the various seismic codes of the world. Clarification of these differences is necessary.

\subsection{Anchorage of longitudinal bars in interior beam- column joints}

The plastic hinges in the beams normally occur near the beam ends and hence during seismic loading the top and bottom beam bars may yield in tension and compression alternatively at the column faces. The high bond stresses on the longitudinal bars in the joint core may lead to significant bond deterioration and some bar slip through the joint core. As a result of this slip a beam bar can be close to yield in compression at one column face and at yield in tension at the other column face. Design standards generally attempt to reduce bar slip by limiting the bond stresses by specifying maximum values for the $d_{b} / h_{c}$ ratio for the joint where $d_{b}$ is the diameter of the beam bar and $h_{c}$ is the depth of the column.

For concrete compressive strength $f_{c}^{\prime}$ in the range 20-40 $\mathrm{MPa}$ and steel yield strength $\mathrm{f}_{\mathrm{y}}$ the range $300-400 \mathrm{MPa}$ the maximum permitted values for $\mathrm{d}_{\mathrm{b}} / \mathrm{h}_{\mathrm{c}}$ of top bars (see Hakuto, et al [35] according to EC 8 [1] vary between $1 / 18$ and $1 / 43$, according to the AIJ guidelines [2] vary between $1 / 15$ and $1 / 35$, and according to the New Zealand standard [4] vary between $1 / 17$ and 1/35. In each case the larger permitted $\mathrm{d}_{\mathrm{b}} / \mathrm{h}_{\mathrm{c}}$ value applies to the higher strength concrete $\mathrm{f}_{\mathrm{c}}^{\prime}=40$ $\mathrm{MPa}$ and lower yield strength steel $\left(\mathrm{f}_{\mathrm{y}}=300 \mathrm{MPa}\right)$.

However, the ACI code [3] recommends a single constant maximum permitted value for $d_{b} / h_{c}$ of $1 / 20$ and hence places less emphasis is on limiting the bar slip.

In New Zealand it is recognised that some bar slip is inevitable, but significant slip during a severe earthquake is considered to be undesirable for three main reasons: (1) It 
leads to a considerable reduction in stiffness of the frame which is residual, (2) bond deterioration is difficult to repair by epoxy resin injection, and (3) it leads to a reduction in the available curvature ductility factor of the adjacent plastic hinges in the beams.

Note that if the bond deterioration is significant the bar tension will penetrate through the joint and the bar tensile force will be anchored in the beam on the other side of the joint. This means that the "compression" steel there will actually be in tension. The result is that, although the flexural strength of the beam may not be greatly reduced (except for large steel ratios), the available ultimate curvature at a specified ultimate concrete compressive strain is very greatly reduced.

For example analyses of rectangular beams with $f_{c}^{\prime}=30$ $\mathrm{MPa}$ and $\mathrm{f}_{\mathrm{y}}=300 \mathrm{MPa}$ and reinforcement ratio for the top reinforcement of $1.67 \%$ and for the bottom reinforcement of $0.67 \%$ for the stage when the "compression" reinforcement just reached yield in tension have been conducted (see Hakuto et al [35]). It was found that the reduction in flexural strength was $5-10 \%$ (depending on the moment direction) when compared with the flexural strength when there was perfect bond (no slip) along the beam bars. The available curvature ductility factor, $\phi_{\mathrm{u}} / \phi_{\mathrm{y}}$ where $\phi_{\mathrm{u}}=$ ultimate curvature and $\phi_{y}=$ curvature at first yield, reduced to 5 whereas it was 12-18 (depending on the moment direction) for perfect bond. It is evident that the maximum $d_{b} / h_{c}$ values specified for seismic design by standards and codes is a matter of judgement. Some bond deterioration is inevitable, and should be accepted. The considerations are that, on the one hand, a too small a specified $\mathrm{d}_{\mathrm{b}} / \mathrm{h}_{\mathrm{c}}$ ratio will lead to the necessity for small diameter bars and/or large columns which results in design and construction difficulties. On the other hand a large specified $d_{k} / h_{c}$ ratio will lead to significant bond deterioration during a severe earthquake, resulting in a

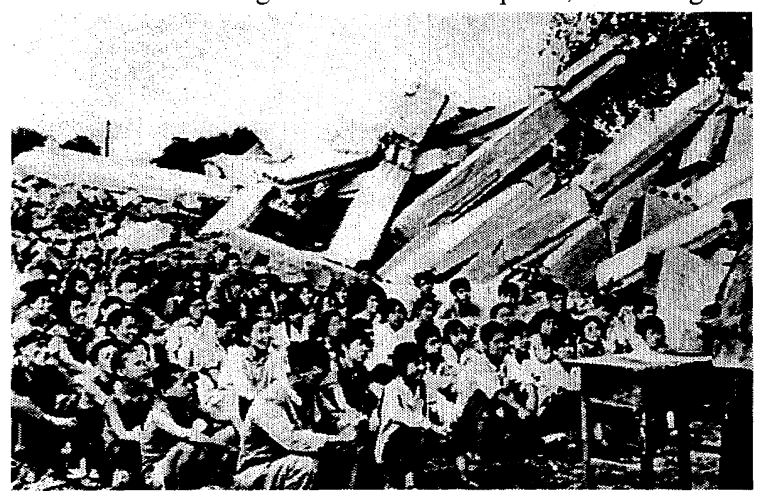

a. reduction in stiffness of the frame, flexural strength and available curvature ductility factor.

\section{PRECAST CONCRETE}

\subsection{Introduction}

Precast reinforced and prestressed concrete has had significant and successful application in earthquake resisting structures in many parts of the world. Experience of earthquakes and laboratory testing gives confidence that precast reinforced and prestressed concrete elements can be used very successfully in structures designed for earthquake resistance providing careful attention is paid to design and construction. Poorly designed and constructed precast reinforced concrete structures have performed badly in some major earthquakes due to brittle (non-ductile) behaviour of poor connection details between the precast elements, poor detailing of the elements, and poor design concepts. Figure 11 shows examples of major damage to poorly designed and constructed precast concrete structures as a result of severe earthquakes. This has resulted in the use of precast concrete in earthquake resisting structures being regarded with suspicion in some countries. However, experience has shown that structures incorporating precast concrete elements which are well designed and constructed for seismic resistance will perform well in earthquakes [36].

The design and construction of precast concrete structures to resist seismic actions requires an appreciation of product, erection and interfacing tolerances. The designer and erector must possess knowledge of the capabilities and limitations of precast element processes, and an understanding of how the structure will be safely assembled.

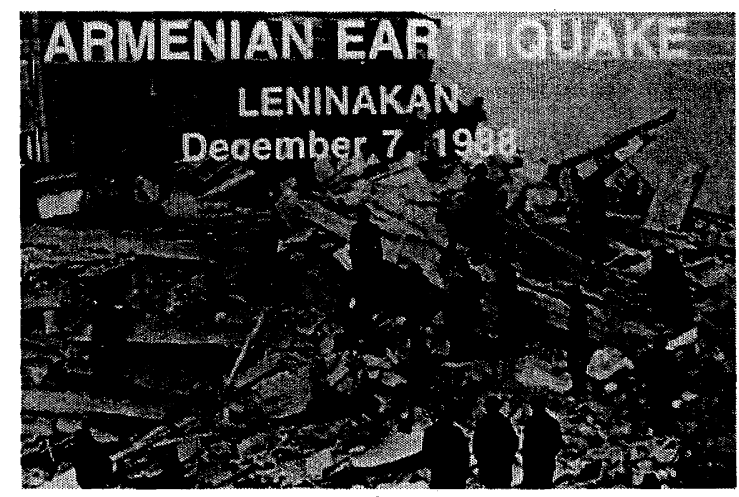

b.

Figure 11. Collapse of poorly designed and constructed precast concrete buildings [36] (a). Tangshan, China 1976, (b). Leninakan, Armenia, 1988.

Codes contain provisions for the design of precast concrete in seismic regions to various degrees. For example, seismic provisions for precast concrete are scattered throughout the New Zealand concrete design standard [4]. The ACI building code in its 2002 edition [3] has seismic provisions for precast concrete but does not permit the option of nonemulative precast wall structures. The Architectural Institute of Japan has published draft design guidelines for precast construction of equivalent monolithic reinforced concrete buildings [37]. EC8 [1] has a comprehensive section with seismic provisions for precast concrete buildings. 


\subsection{Lateral force resisting systems}

Lateral force resisting systems are generally either moment resisting frames or structural walls, or dual frame-wall systems. In general when built incorporating precast concrete elements they are either "equivalent monolithic" or "jointed" systems. The distinction between these two systems is based on the design of the connections between the precast concrete elements.

In equivalent monolithic systems the connections are designed to emulate the performance of cast-in-place concrete construction and may be either ductile connections of the required strength designed to yield, or strong connections of limited ductility designed to remain in the elastic range when the building is satisfying the ductility demand imposed by a severe earthquake. In jointed systems the connections are weaker than the adjacent precast concrete elements. Jointed systems do not emulate the performance of cast-in place concrete construction.

\subsection{Ductile equivalent monolithic reinforced concrete moment resisting frames incorporating precast concrete elements}

(a) Arrangement of members:

Four equivalent monolithic ductile reinforced concrete construction systems used in Japan (Architectural Institute of Japan [37] and New Zealand (Centre for advanced Engineering [38] designed for weak beamstrong column behaviour are shown in Fig. 12.

In System 1 the precast concrete beam elements are placed between either precast or cast-in-place concrete columns, seated on the cover concrete below and/or propped adjacent to the columns. Reinforcement is then placed in the top of the beams and in the beam-column joint cores. One approach with this system, typically used in New Zealand, is to splice the beam bottom bars using hooked anchorages in the joint core (see (a) of System 1). An alternative approach, typically used in Japan, is for the bottom bars to be continuous through the joint (see (b) of System 1). The faces of the precast beam elements are either keyed or roughened.

In System 2 the vertical column bars of the column below the joint protrude up through vertical corrugated steel ducts in the beam unit where they are grouted and pass into the column above. The beams are connected using a cast-in-place concrete joint at midspan (see Fig. 12).

In System 3, T-shaped or cruciform shaped precast concrete elements are connected vertically by column bars and horizontally by a cast-in-place concrete joint at midspan (see Fig. 12).

In System 4, mainly used in New Zealand, pretensioned prestressed concrete U-beam and cast-in-place reinforced concrete are used (see Fig. 12).
In all systems a precast concrete floor system is placed seated on the top of the precast concrete beam elements and spanning between them.

(b) Column-to-column and beam-to-beam connections:

The precast reinforced concrete elements in Systems 2 and 3 can be spliced either at the end above the beam or at mid-height. Either grouted steel sleeves (see Fig. 13(a)) or non-contact lap splices involving grouted corrugated steel ducts can be used (see Fig. 13(b)). In Fig. 13(b) the longitudinal bars protruding from the precast column bars " $G$ " are grouted into corrugated metal ducts in the mating column. Adjacent to the ducts there are two smaller diameter bars, bars "L", of about the same cross sectional area as the grouted bar. Those bars are lap spliced a distance not less than the same time as the ducts. Note that splices at the end of columns can be protected by a capacity design approach to prevent plastic hinging occurring in the column there.

The precast reinforced concrete beam elements in Systems 2 and 3 are connected by a cast-in-place concrete joint near midspan (see Fig. 14). In New Zealand bar laps are favoured. Straight bar laps are used if the cast-in-place joint is long enough (see Fig. 14(a) and (b)).

Alternatively for shorter cast-in-place joints hooked bar laps can be used or double hooked drop-in-bars (See Fig. 14(c)). The details shown in Fig. 14(b) and (c) are easier to assemble during erection. In Japan welding the bars or mechanical couplers, or grouted steel sleeves (see Fig. 14(d) and (e)) are favoured.

\subsection{Jointed reinforced concrete moment resisting frames of limited ductility incorporating precast} concrete elements

Some jointed reinforced concrete moment resisting frame systems that have relatively weak connections between precast elements, achieved mainly by welding or bolting and dry packing, have been attempted. Such systems should be used with caution since they can have very limited ductility.

\subsection{Ductile hybrid jointed moment resisting frames incorporating precast concrete elements}

Hybrid systems are jointed systems which combine unbonded post-tensioned tendons with longitudinal nonprestressed reinforcing bars. Hybrid systems were developed in the United States and adopted in the PRESSS (Precast Seismic Structural Systems) programme (Priestley et al, [39]). Figure 15 shows an example. The precast concrete beams are connected to multi-storey columns by unbonded post-tensioned tendons that run through a PVC duct at the centre of the beam. The gap between the beam and the precast column is filled with fibre reinforced grout. 


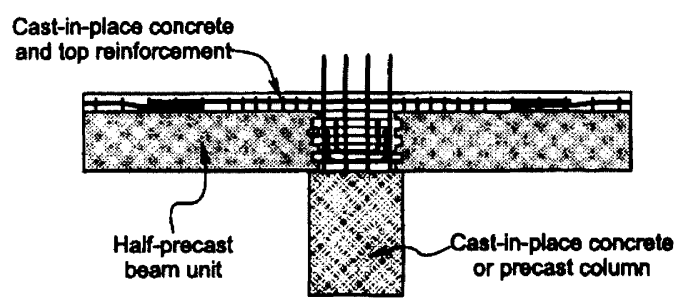

(a) Approach using hooked bottom bar anchorages

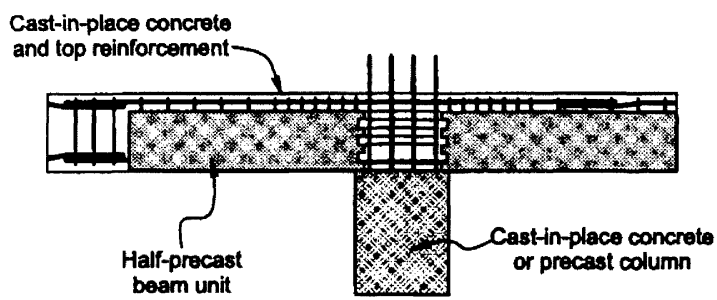

(b) Approach using straight bottom bars

Systom 1
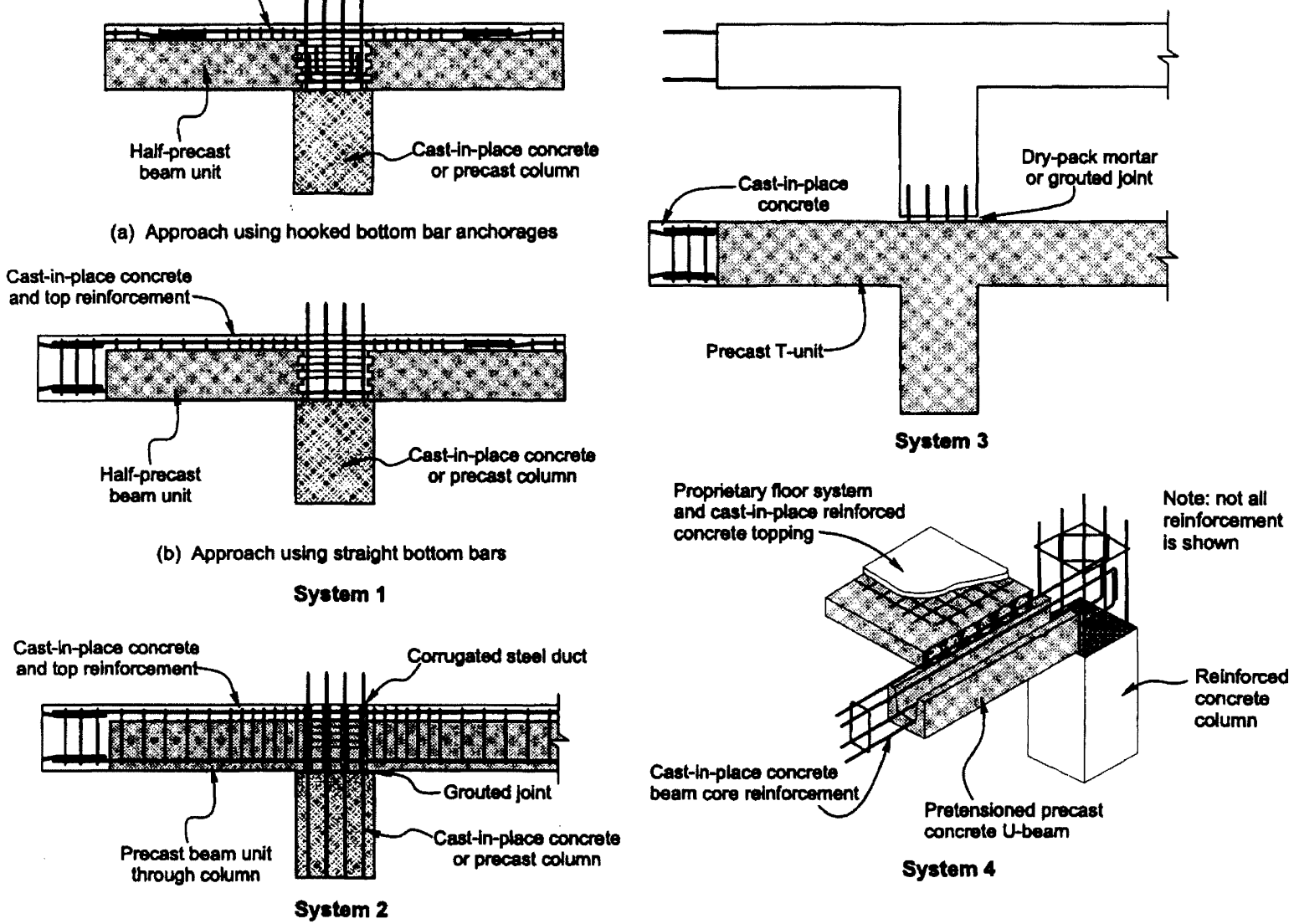

Figure 12. Ductile equivalent monolithic reinforced concrete moment resisting frame Systems 1, 2, 3 and 4 [36].

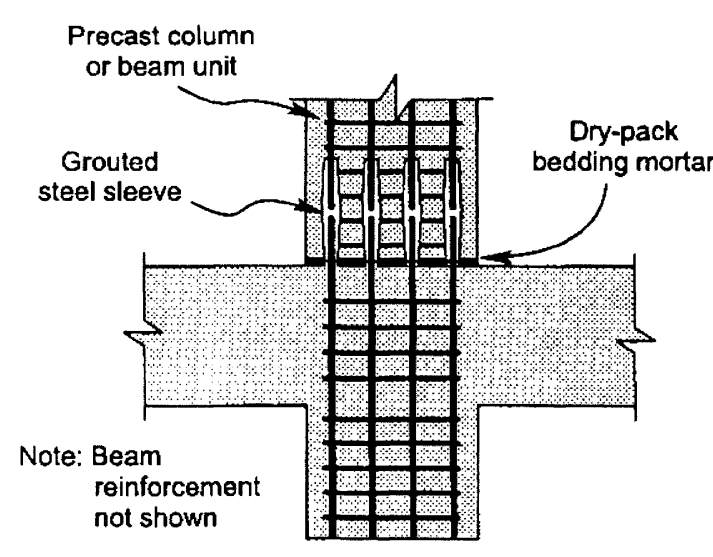

(a) Grouted steel sleeves

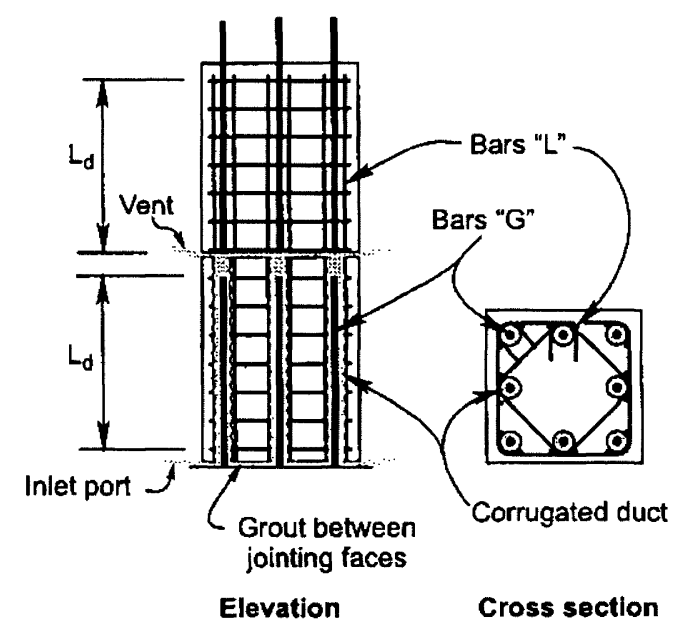

(b) Non-contact lap bar splices

Figure 13. Column-to-column reinforced concrete connections [36]. 


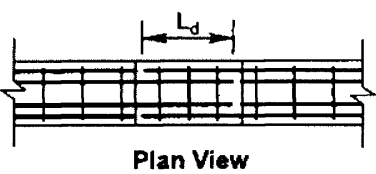

Plan View

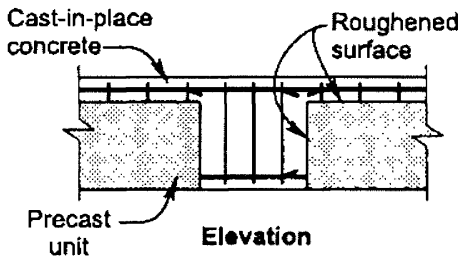

(a) Straight bar laps

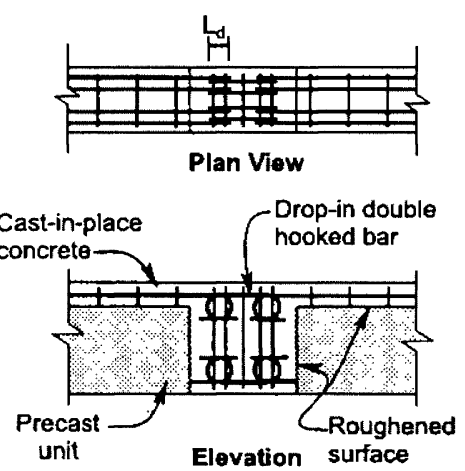

(c) Double hooked bar laps

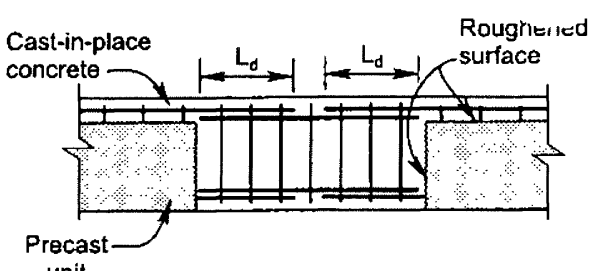

(b) Double straight bar laps

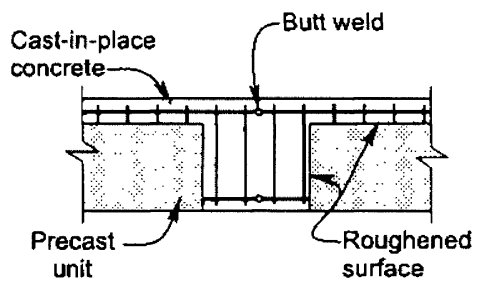

(d) Welded bars

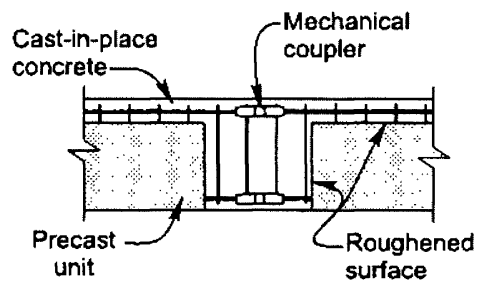

(e) Mechanically coupled bars

Figure 14. Beam-to-beam reinforced concrete connections.

The tendon prestress is such as to ensure it will not reach the limit of proportionality during an earthquake. Nonprestressed steel reinforcing bars are placed in corrugated ducts on the top and bottom of the beam and through the columns and grouted. These bars provide energy dissipation by yielding in tension and compression over debonded regions next to the beam-to-column connection. The nonlinear deformations come from the opening and closing of the crack at the interface between the precast concrete elements. The system has the advantage of reduced damage during an earthquake and of being self-centering (ie, practically no residual deflection after an earthquake).

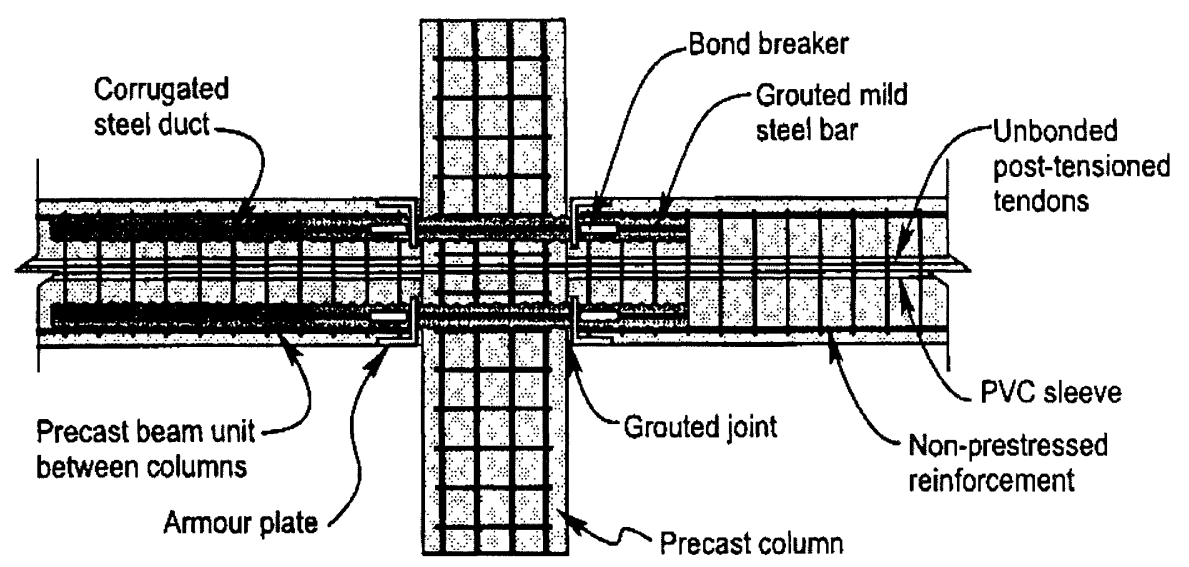

Figure 15. General reinforcing details of a hybrid frame system [39]. 


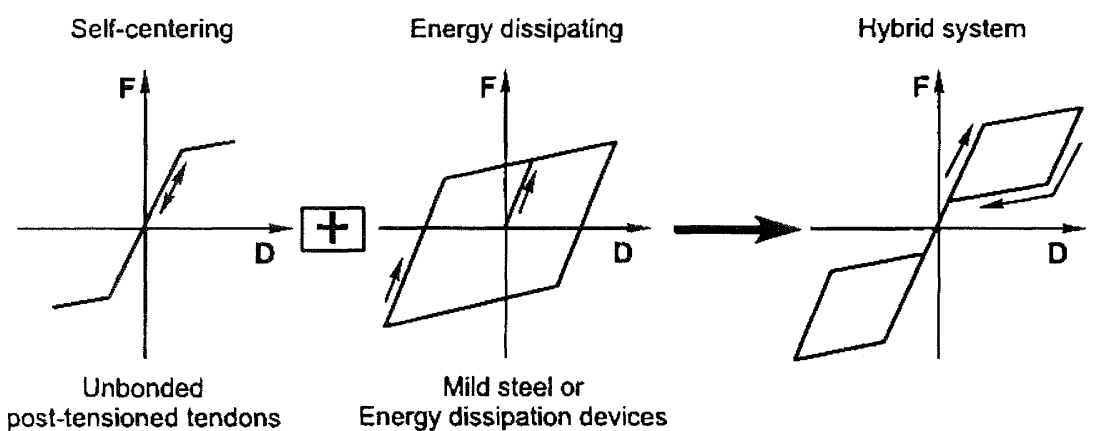

Figure 16. Idealised flag-shape hysteretic rule for a hybrid system [36].

Figure 16 shows the idealized flag-shape hysteretic rule for a hybrid system composed of the sum of the self-centering contribution of the unbonded post-tensioned tendons and the energy dissipation of the mild steel reinforcing bars [36].

\subsection{Equivalent monolithic reinforced concrete structural walls incorporating precast concrete elements}

New Zealand practice for horizontal and vertical joints in monolithic structural wall construction is discussed below.

At the horizontal joints between precast reinforced concrete wall panels or foundation beams the ends the panels are usually roughened to avoid sliding shear failure and the joint made using mortar or grout. The vertical reinforcement protruding from one end of the panel and crossing the joint is connected to the adjacent panel or foundation beams by means of either grouted steel splice sleeves or grouted corrugated metal ducts much as for the column-to-column connections in Fig. 13.

Vertical joints between precast concrete wall panels are typically strips of cast-in-place concrete into which horizontal reinforcement from the ends of the adjacent panels protrude and are lapped. Fig 17 shows some possible vertical joint details between precast wall panels that make use of cast-in-place concrete. The widths of the strips of cast-inplace concrete are determined by code requirements for lap lengths of horizontal reinforcement. Fig. 17(a) shows a joint with sufficient width to accommodate the lap splice length of the straight horizontal bars that protrude from the precast wall panels. Fig. 17(b) shows hooked lap splices that enable the width of joint to be reduced. Fig. 17(c) and (d) show hairpin splice bars which may not be convenient to construct since once the lapping bars have been overlapped the ability to lower the precast panels over starter bars is very restricted.

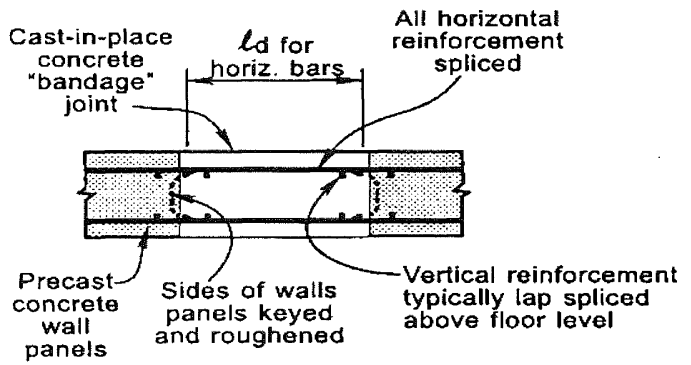

(a) Straight Lap Splices

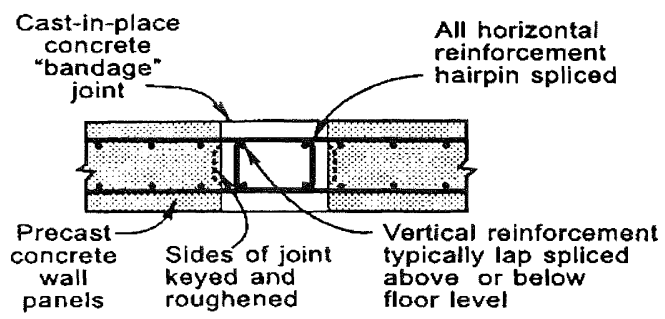

(c) Hairpin Lap Splices

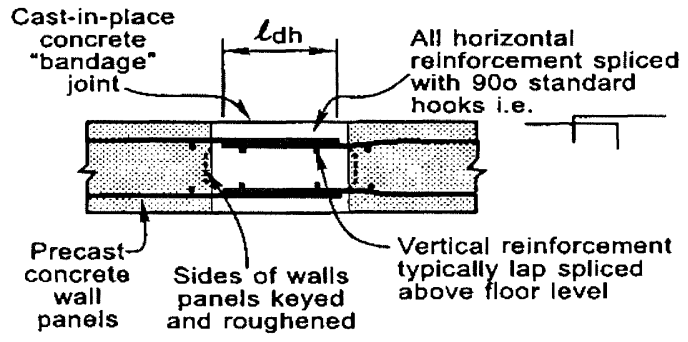

(b) Hooked Lap Splices

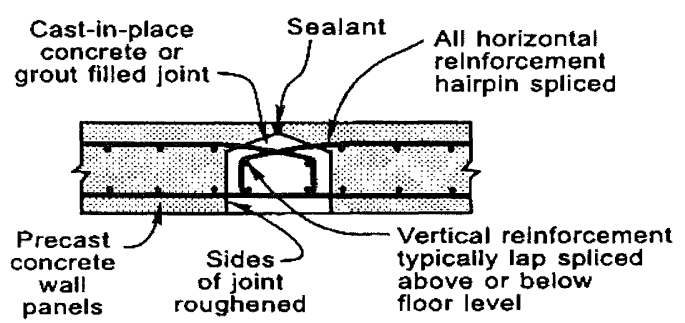

(d) Hairpin Lap Splices

Figure 17. Examples of vertical joints for equivalent monolithic precast reinforced concrete structural wall construction [36]. 

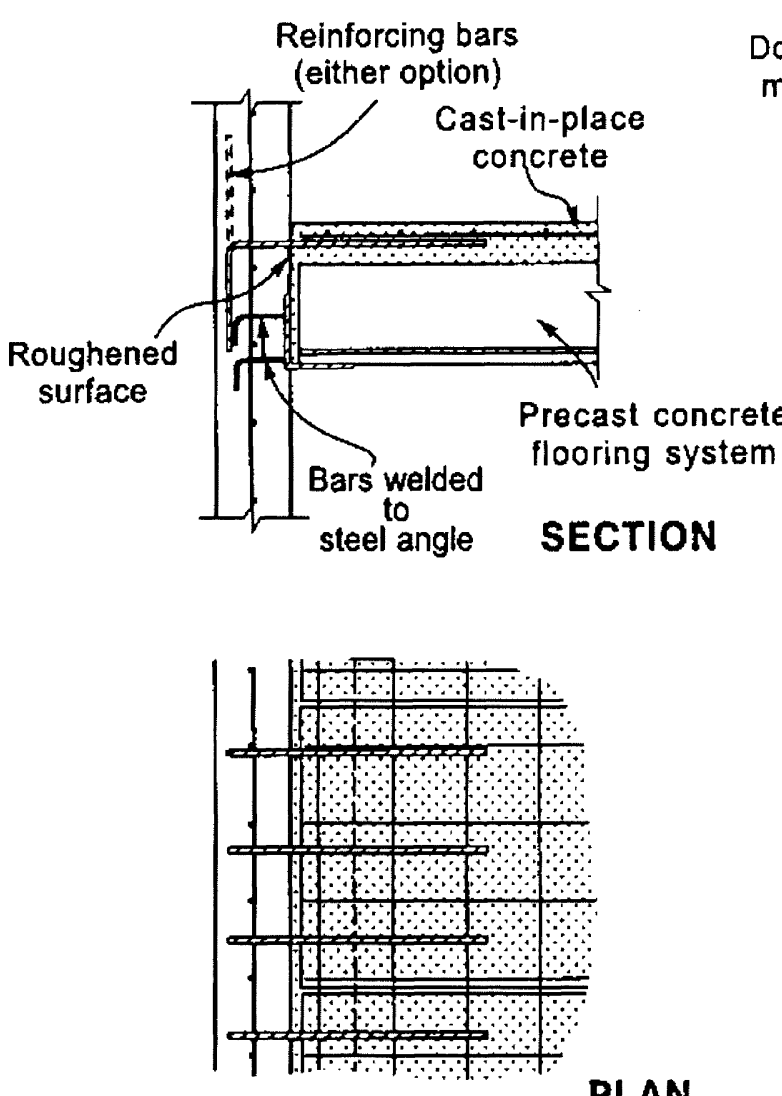

PLAN
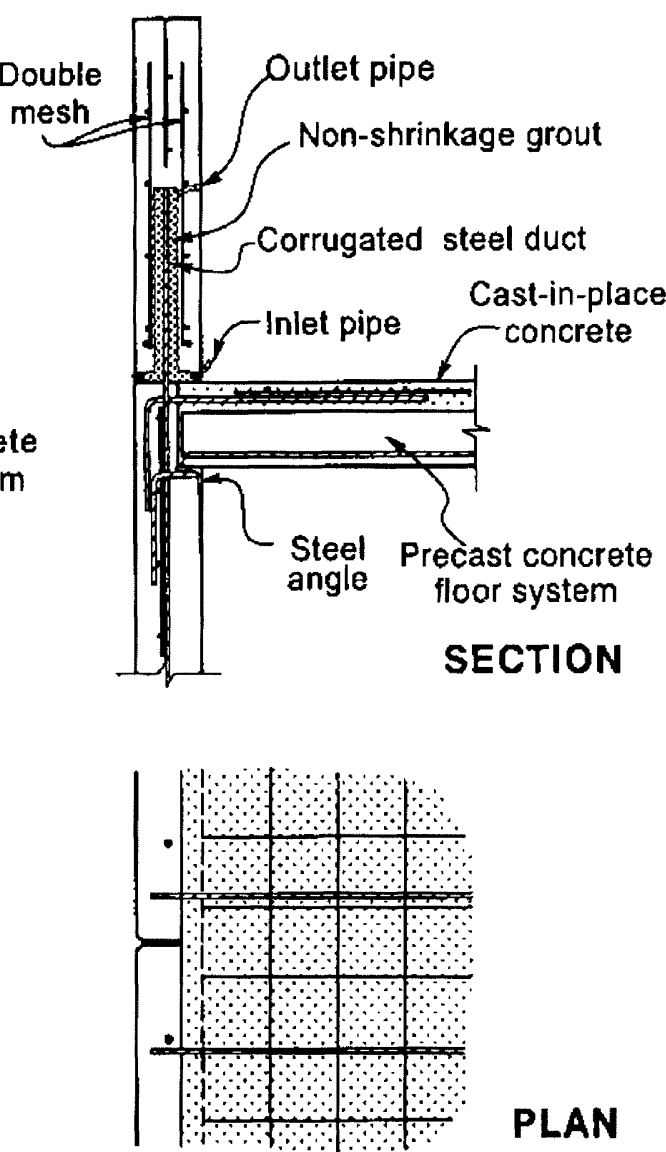

PLAN

(b) Segmented wall with recess and grouted horizontal joint

Figure 18. Examples of precast reinforced concrete exterior wall-to-precast slab floor connections [36].

Support for precast floor units at walls can be achieved in a number of ways. Figure 18 shows two examples for exterior walls. In Fig. 18(a) the precast wall panel is continuous through the connection and the floor is seated on a steel angle anchored to the precast wall panel. Alternatively a concrete corbel could be used. In Fig. 18(b) the precast wall panel is segmented and the floor is seated on a recess in the wall.

\subsection{Jointed reinforced concrete structural walls of limited ductility incorporating precast concrete elements}

In jointed wall construction of limited ductility the connection between the precast reinforced concrete wall panels is such that planes of significantly reduced stiffness and strength exist at the interface between adjacent precast concrete wall panels. Such construction has been extensively used in New Zealand in tilt-up construction generally of one to three storey apartment, office and industrial buildings.
Generally tilt-up wall panels are secured to the adjacent elements using jointed connections comprising various combinations of concrete inserts, bolted or welded steel plates or angle brackets, and lapped reinforcement splices within cast-in-place joining strips. Tilt-up construction is generally designed for elastic or limited ductile response.

\subsection{Ductile hybrid structural walls}

Hybrid structural walls are jointed walls, which contain unbonded post-tensioned tendons with longitudinal steel reinforcement and/or other energy dissipating devices. They were developed in the United States and adopted in the PRESSS Programme (Priestley et al, [39]). Figure 19 shows a wall system adopted. The post-elastic demand is concentrated at the joints. Figure 16 shows the idealized flag-shaped hysteretic rule also of the hybrid wall. 


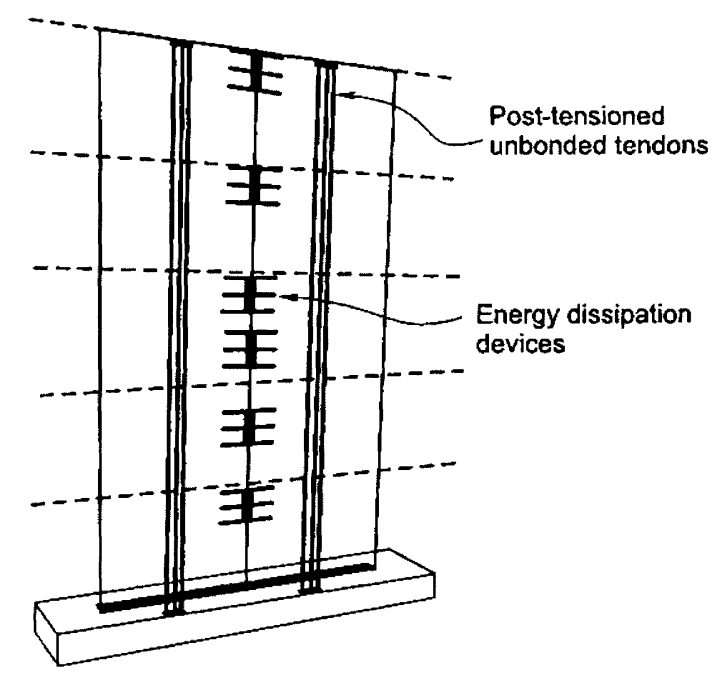

Figure 19. A hybrid structural wall system developed in the PRESSS programme (Priestley et al [39]).

\subsection{Diaphragms}

As well as carrying gravity loading, floors and roofs need to transfer the in-plane imposed wind and seismic forces to the supporting structures through diaphragm action. A convenient way to achieve diaphragm action when precast concrete floor and roof elements are used is to provide a castin-place reinforced concrete topping slab over the precast units. Where precast concrete floor and roof units are used without an effective cast-in-place concrete topping slab, inplane force transfer due to diaphragm action must rely on appropriately reinforced joints between the precast units. In Italy topping slabs may not be preferred [36].

Adequate support of precast concrete floor and roof units is one of the most basic requirements for a safe structure. The units should not lose their support. One source of movements during severe earthquakes, which could cause precast concrete floor and roof units to become dislodged, is that beams of ductile moment resisting frames tend to elongate when forming plastic hinges, which could cause the distances spanned by precast concrete floor and roof members to increase. This elongation may be in the order of $2-4 \%$ of the beam depth per plastic hinge (Centre for Advanced Engineering, [38]) as has been observed in tests where expansion was free to occur. This elongation occurs because of the extension of longitudinal reinforcement in the beams due to plastic strains. It may cause tearing away of diaphragms in extreme events [36].

Two possible types of support for precast concrete hollowcore or solid slab flooring units seated on precast concrete beams, identified by the New Zealand guidelines (Centre for Advanced Engineering, [38]) are shown in Figure 20. The differences between these types are the depth of the supporting beam prior to the cast-in-place concrete being placed. Figure 20 also shows special support reinforcement intended to carry the vertical load in the event of the precast floor units losing their seating. For precast hollowcore units it can either be placed in some of the cores which have been broken out at the top and filled with cast-in-place concrete or it can be grouted into gaps between the precast units. Plain round well anchored reinforcement is used. Bond failure propagating along the plain round bars results in extensive yielding along the bars therefore allowing substantial plastic elongation before fracture.

Other sources of localised displacements in diaphragms, as well as elongation at plastic hinges in reinforced concrete beams, are strut and tie node points where diaphragm forces pass around floor openings or irregularities in floor plan, transfer diaphragms, sliding joints in vertically jointed walls, and pinned-end beams.

Two procedures that can be used to accommodate these displacements are:

(1) Isolate the precast components from any high displacement demands, with sliding supports and/or compressible joints. This method is preferred for relatively brittle extruded or slip-formed hollowcore sections, and for some of the more brittle beam and block flooring systems.

(2) Reinforce the precast units, and any composite topping concrete to provide adequate ductility to resist the required gravity loads during, and after, the imposed displacement (for example as in Fig. 20). 


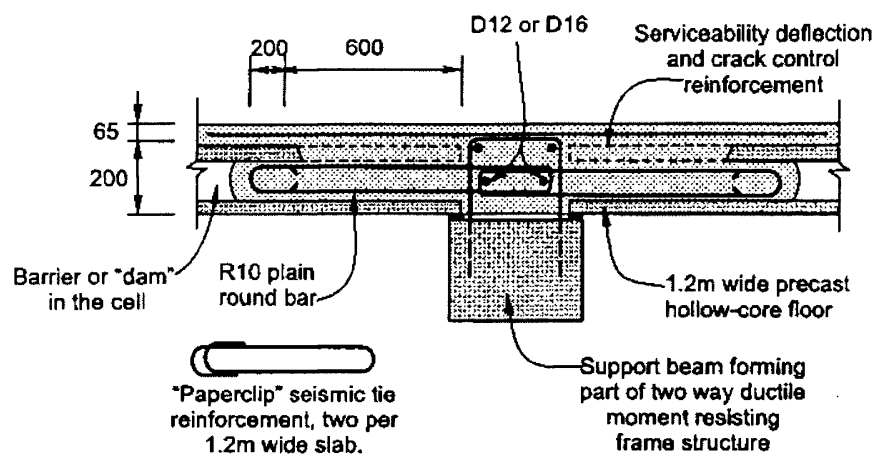

(a) For Type 1 Support

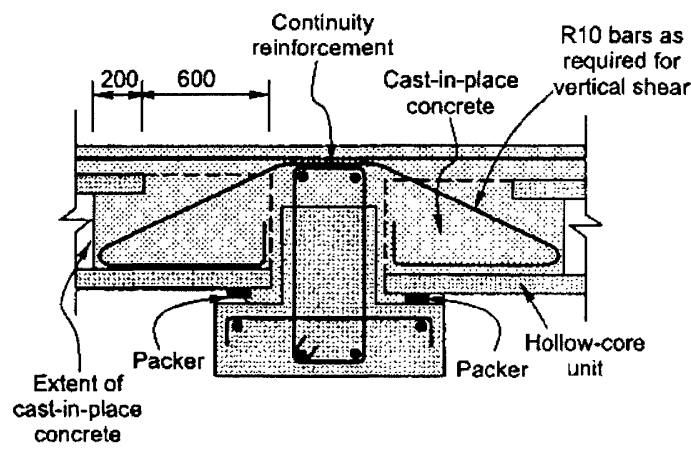

(b) For Type 2 Support

Figure 20. Examples of support and special support reinforcement at ends of precast concrete hollowcore floors (Centre for Advanced Engineering [38]).

\section{CONCLUSIONS}

(1) During the last 50 or so years a great deal of research and development has been conducted into the design of reinforced concrete building structures subjected to seismic actions. However, significant differences exist between the codes and guidelines for reinforced concrete of different countries.

(2) Current seismic codes tend to emphasise life safety. More refined performance criteria for reinforced concrete building structures are required to avoid unacceptable damage during various levels of earthquakes.

(3) More accurate recommendations for the flexural rigidity of reinforced concrete members are required for linear elastic analysis of statically indeterminate structures, taking into account the effects of cracking of concrete, to enable better estimates of periods of vibration and lateral deflections of building structures.

(4) The capacity design approach to ensure the most appropriate mechanism of yielding of building structures in the event of an earthquake offers the advantages of a rational design procedure and a greater reliability of seismic performance. The capacity design approach has been implemented to varying degrees in the seismic design codes throughout the world.

(5) High strength concrete and high non-prestressed reinforcement may need special provisions when used in seismic design. High strength concrete when used in columns needs large quantities of confining reinforcement to ensure ductile behaviour, which can be provided by high strength transverse reinforcement. The useable yield strength of high strength reinforcement needs to be considered. The use of high strength longitudinal reinforcement leads to high curvatures at first yield which can result in a reduced available displacement (structure) ductility for a given drift limitation

(6) Significant differences between seismic codes exist with regard to the qualities of transverse reinforcement required for confinement of columns in potential plastic hinge regions.

(7) Significant differences between seismic codes exist with regard to the quantities of transverse reinforcement required for shear strength and confinement of beamcolumn joints. Differences also exist between the design approaches for the permitted diameters of longitudinal beam bars passing through interior beam-column joints.

(8) Precast concrete structures can be designed successfully for earthquake resistance but design codes contain provisions for precast concrete to varying degrees. Important design aspects are the design concepts used, the connection details between precast concrete elements, and the detailing of the elements.

\section{REFERENCES}

1. European Committee for Standardisation: Design provisions for earthquake resistance of structures EC 8 (Drafts), Brussels, 1994-2003.

2. Architectural Institute of Japan (1997). Design guidelines for earthquake resistant reinforced concrete buildings based on inelastic displacement concept (Draft), Tokyo, (in Japanese).

3. American Concrete Institute (2002). Building code requirements for structural concrete ACI 318-02, Farmington Hills .

4. Standards New Zealand (1995). The design of concrete structures NZS 3101:1995, Wellington.

5. Standards New Zealand (1992). General structural design and design loadings for buildings NZS 4203:1992, Wellington.

6. Structural Engineers Association of California (1995). Vision 2000: Performance based seismic engineering of buildings, San Francisco. 
7. Osaka, T., Hiraishi, H., Ohashi, Y. (2000). A new frame work for performance-based design of building structures, Proceeding of the Twelfth World Conference on Earthquake Engineering, paper \#2098, Auckland, New Zealand.

8. Priestley, M.J.N. (2000). Performance based seismic design, Bulletin of the New Zealand Society for Earthquake Engineering, Vol. 33, No. 3, September, pp. 325-346.

9. Priestley, M.J.N. (1998). Brief comments on elastic flexibility of reinforced concrete frames and significance to seismic design. Bulletin of New Zealand National Society for Earthquake Engineering, Vol. 31, No. 4, December, pp 246-258.

10. Park, R. and Paulay, T. (1975). Reinforced concrete structures. John Wiley and Sons, New York, 769 pp.

11. Park, R. and Paulay, T. and Bull, D.K. (1992). Seismic design of reinforced concrete structures. Technical Report No. 20, New Zealand Concrete Society, Wellington, September.

12. Standards Association of New Zealand (1989). Steel bars for the reinforcement of concrete NZS 3402:1989, Wellington.

13. Andriano, T. and Park, R. (1986). Seismic design considerations of the properties of New Zealand manufactured steel reinforcing bars, Bulletin of the New Zealand National Society for Earthquake Engineering, Vol. 19, No. 3, September, pp. 213-246.

14. Zahn, F.A., Park, R. and Priestley, M.J.N. (1986). Design of reinforced concrete bridge columns for strength and ductility, Research report 86-7, Department of Civil Engineering, University of Canterbury, March, $330 \mathrm{pp}$.

15. Cheung, P.C., Paulay, T. and Park, R. (1991). Mechanisms of slab contributions in beam-column subassemblages. Design of Beam-Column Joints for Seismic Resistance, Special Publication, SP-123, American Concrete Institute, pp. 259-289.

16. Hollings, J.P. (1969). Reinforced concrete seismic design. Bulletin of New Zealand National Society for Earthquake Engineering, Vol. 2, No. 3, pp. 217-250.

17. Paulay, T. and Priestley, M.J.N. (1992). Seismic design of reinforced concrete and masonry buildings. John Wiley and Sons, New York, 744 pp.

18. Park, R. (1986). Ductile design approach for reinforced concrete frames. Earthquake Spectra, Vol. 2, No. 3, May, pp. 565-619.

19. Paulay, T. (1997). Evaluation of actions, report of discussion group on seismic design of ductile moment resisting reinforced concrete frames. Bulletin of New Zealand National Society for Earthquake Engineering, Vol. 10, No. 2, June, pp. 85-94
20. Booth, E.D., Kappos, A.J., Park, R., Moehle, J.P. and Hikone, S. (1998). Seismic design of concrete frame structures : A comparison of Eurocode 8 with other international practice, Proceedings of the $6^{\text {th }}$ Conference of the Society for Earthquake and Civil Engineering Dynamics, Oxford, United Kingdom, March, pp. 481492.

21. International Conference of Building Officials: Uniform building code, Whittier, California, 1997.

22. Pinto, P.E., Colangelo, F. and Giannini, R. (1995). Stochastic Iinearization technique for the calibration of capacity design factors of RC frames, Institut für Baustatik und Konstruktion, ETH Zürich, IBK Publikation SP-004.

23. Panagiotakos, T.B., and Fardis, M.N. (1998). Effect of column capacity design on earthquake response of reinforced concrete buildings. Journal of Earthquake Engineering, Vol. 2, No. 1, pp. 113-145.

24. Dooley, K.L. and Braci, J.M. (2001). Seismic evaluation of column-to-beam strength ratios in reinforced concrete frames. Structural Journal of American Concrete Institute, Vol. 98, No. 4, November-December, pp. 843851.

25. Maffei, J., Stanton, J., Priestley, M.J.N. and Park, R. (2003). Chapter 4 Design approaches, State-of-the-art report on the seismic design of precast concrete structures, Task Group 7.3 of Commission 7 , International Federation for Structural Concrete (fib).

26. Li Bing, Park, R. and Tanaka, H. (1991). Effect of confinement on the behaviour of high strength concrete columns under seismic loading, Proceedings of Pacific Conference on Earthquake Engineering, Vol. 1, Auckland, November, pp. 67-78.

27. Paulay, T. (2000). A note on new yield stress, Journal of the Structural Engineering Society of New Zealand, Vol. 13, No. 2, September, pp. 43-44.

28. Park, R. (2001). The use of the new Grade 500E manufacturing steel, Journal of the Structural Society of New Zealand, Vol. 14, No. 1, pp 29-31.

29. Mander, J.B., Priestley, M.J.N. and Park, R. (1988), Theoretical stress-strain model for confined concrete. Journal of Structural Engineering of the American Society for Civil Engineers, Vol. 114, No. 8, August, pp. 1804-1826.

30. Mander, J.B., Priestley, M.J.N. and Park, R. (1988) Observed stress-strain behaviour of confined concrete. Journal of Structural Engineering of the American Society for Civil Engineers, Vol. 114, No. 8, August, pp. 1827-1849.

31. Watson, S., Zahn, F.A., and Park, R. (1994). Confining reinforcement for concrete columns. Journal of 
Structural Engineering of American Society of Civil Engineers, Vol. 120, No. 6, June, pp. 1798-1824.

32. Watson, S. and Park, R. (1994). Simulated seismic load tests on reinforced concrete columns. Journal of Structural Engineering of American Society of Civil Engineers, Vol. 120, No. 6, June, pp. 1825-1849.

33. Park, R. (2002). Some considerations in the seismic design of reinforced concrete interior beam-column joints of moment resisting frames, Journal of the Structural Engineering Society of New Zealand, Vol. 15, No. 2, September, pp. 53-64.

34. Nineteen papers from the USA, New Zealand, Japan and China (1991). "Design of Beam-Column Joints" for Seismic Resistance", American Concrete Institute SP123 (J O Jirsa, Editor).

35. Hakuto, S., Park, R. and Tanaka, H. (1999). Effect of deterioration of bond of beam bars passing through interior beam-column joints on flexural strength and ductility, Structural Journal of American Concrete
Institute, Vol. 96, No. 5, September-October, pp. 858 864

36. International Federation for Structural Concrete (fib) (2003). State-of-the-art report on the seismic design of precast concrete structures, Task Group 7.3 of Commission 7, Lausanne.

37. Architectural Institute of Japan (2000). Draft Japanese design guidelines for precast construction of equivalent monolithic reinforced concrete buildings, Tokyo.

38. Centre for Advanced Engineering: Guidelines for the use of precast concrete in buildings (1991). University of Canterbury, Christchurch, New Zealand, $1^{\text {st }}$ edition 1991, $2^{\text {nd }}$ edition $1999,144 \mathrm{pp}$.

39. Priestley, M.J.N., Sritharan, S., Conley, J.R. and Pampanin, S. (1999). Preliminary results and conclusions from the PRESSS five-storey precast concrete test building. Journal of the Precast/Prestressed Concrete Institute, Vol. 44, No. 6, pp. 42-67. 